\title{
Regional climate model experiments to investigate the Asian monsoon in the Late Miocene
}

\author{
H. Tang ${ }^{1}$, A. Micheels ${ }^{2,3}$, J. Eronen ${ }^{1}$, and M. Fortelius ${ }^{1}$ \\ ${ }^{1}$ Department of Geosciences and Geography, P.O. Box 64, 00014, University of Helsinki, Helsinki, Finland \\ ${ }^{2}$ Biodiversity and Climate Research Centre (LOEWE BiK-F), Senckenberganlage 25, 60325, Frankfurt/Main, Germany \\ ${ }^{3}$ Senckenberg Research Institute and Nature Museum, Senckenberganlage 25, 60325, Frankfurt/Main, Germany
}

Received: 2 February 2011 - Published in Clim. Past Discuss.: 1 March 2011

Revised: 16 June 2011 - Accepted: 28 June 2011 - Published: 9 August 2011

\begin{abstract}
The Late Miocene (11.6-5.3 Ma) is a crucial period in the history of the Asian monsoon. Significant changes in the Asian climate regime have been documented for this period, which saw the formation of the modern Asian monsoon system. However, the spatiotemporal structure of these changes is still ambiguous, and the associated mechanisms are debated. Here, we present a simulation of the average state of the Asian monsoon climate for the Tortonian (11$7 \mathrm{Ma}$ ) using the regional climate model CCLM3.2. We employ relatively high spatial resolution $\left(1^{\circ} \times 1^{\circ}\right)$ and adapt the physical boundary conditions such as topography, land-sea distribution and vegetation in the regional model to represent the Late Miocene. As climatological forcing, the output of a Tortonian run with a fully-coupled atmosphere-ocean general circulation model is used. Our regional Tortonian run shows a stronger-than-present East Asian winter monsoon wind as a result of the enhanced mid-latitude westerly wind of our global forcing and the lowered present-day northern Tibetan Plateau in the regional model. The summer monsoon circulation is generally weakened in our regional Tortonian run compared to today. However, the changes of summer monsoon precipitation exhibit major regional differences. Precipitation decreases in northern China and northern India, but increases in southern China, the western coast and the southern tip of India. This can be attributed to the changes in both the regional topography (e.g. the lower northern Tibetan Plateau) and the global climate conditions (e.g. the higher sea surface temperature). The spread of dry summer conditions over northern China and northern Pakistan in our Tortonian run further implies that the monsoonal climate may not have been
\end{abstract}

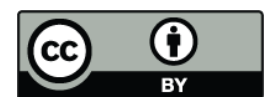

Correspondence to: $\mathrm{H}$. Tang (hui.tang@helsinki.fi) fully established in these regions in the Tortonian. Compared with the global model, the high resolution regional model highlights the spatial differences of the Asian monsoon climate in the Tortonian, and better characterizes the convective activity and its response to regional topographical changes. It therefore provides a useful and compared to global models, a complementary tool to improve our understanding of the Asian monsoon evolution in the Late Miocene.

\section{Introduction}

The Late Miocene (11.6-5.3 Ma) is an important stage for the Asian monsoon evolution (e.g. Zachos et al., 2001; Wang et al., 2005; Molnar et al., 2010). Early evidence indicates the inception or a marked strengthening of the monsoon system in both S-Asia (e.g. Quade et al., 1989; Kroon et al., 1991) and E-Asia (e.g. Rea et al., 1998; An et al., 2001) at 8-7 Ma. This is attributed to the surface uplift of the Tibetan Plateau (TP) (e.g. Ruddiman and Kutzbach, 1989; Kutzbach et al., 1993; An et al., 2001; Liu and Yin, 2002) and the retreat of the Paratethys (e.g. Ramstein et al., 1997; Fluteau et al., 1999).

More recent studies, however, challenge this idea, proposing the establishment of the monsoon climate in E-Asia and S-Asia much earlier than the Late Miocene (e.g. Guo et al., 2002; Sun and Wang, 2005; Clift et al., 2008). Instead of the weaker-than-present monsoon in the Late Miocene suggested by earlier studies, a monsoon climate similar to or even stronger than present is documented in recent studies (e.g. Dettman et al., 2001; Clift et al., 2008; Jiang and Ding, 2008). While the former studies emphasize the dominant influence of regional tectonics such as the TP uplift on

Published by Copernicus Publications on behalf of the European Geosciences Union. 
the monsoon changes in the Late Miocene, the latter stresses the predominant impact of the global climate. For instance, it is suggested that the less-than-present global ice volume and prevailing warmer global condition in the Miocene would have led to a strong summer monsoon at that time (e.g. Jiang and Ding, 2008; Passey et al., 2009).

The complex spatial structure is an inherent feature of the modern Asian monsoon systems (e.g. Ding, 1992; Gadgil, 2003; Wang et al., 2008a). The response of the monsoon climate, particularly the monsoon precipitation, to different forcings (e.g. $\mathrm{CO}_{2}$ concentration) varies from region to region (e.g. Zhu and Wang, 2002; Singh and Oh, 2007; Ashfaq et al., 2009). Evidence indicating a complex spatial pattern of the Asian monsoon climate and the corresponding vegetation changes in the late Miocene has also emerged in recent studies (e.g. Passey et al., 2009; Sanyal et al., 2010). Understanding such regional heterogeneity would be essential to unravel the discrepancies in the monsoon proxies and disentangle the mechanisms for the monsoon changes of this period.

Climate simulations with relatively thorough representation of global atmosphere and ocean conditions in the Late Miocene have been performed using different general circulation models (GCMs) (e.g. Dutton and Barron, 1997; Steppuhn et al., 2006, 2007; Micheels et al., 2007, 2011; Lunt et al., 2008). However, all these experiments use coarse spatial resolution, thus lack regional details over the Asian monsoon area. Because of the coarse resolution, these experiments are not able to capture the small-scale topography, which may have exerted substantial impact on the development of the Asian monsoon in the Late Miocene, such as southern Tibet (e.g. Harris, 2006; Boos and Kuang, 2010). Compared to GCMs, regional climate models (RCMs) with high spatial resolution can resolve small-scale physical and dynamical processes, performing better than GCMs in simulating the spatial patterns and the magnitude of the Asian monsoon precipitation (e.g. Gao et al., 2006, 2008). RCMs are also valuable tools for identifying the mechanisms associated with monsoonal circulation (e.g. Park and Hong, 2004; Singh and Oh, 2007). Some studies have applied RCMs to investigate the Asian monsoon in the mid-Holocene and the Last Glacial Maximum, and demonstrated better agreement of their RCM results with relevant geological evidence (Zheng et al., 2004; Ju et al., 2007). However, we are not aware of any regional climate model studies on the preQuaternary Asian monsoon climate.

In this study, the regional climate model CCLM3.2, nested in one-way mode within a fully-coupled atmosphere-ocean general circulation model (AOGCM) (Micheels et al., 2011), is employed to simulate the average state of the Asian monsoon climate in the Tortonian (11-7 Ma). We first compare our regional model results with the driving global model and the monsoon proxies to demonstrate the regional pattern of the monsoon climate in the Tortonian and the adding values of our regional model results. Then, the effect of the Tortonian global forcing and regional boundary conditions is analyzed to further evaluate the contribution of different mechanisms to the Asian monsoon evolution in the Late Miocene.

\section{Model and model setup}

\subsection{The CLM model}

The CLM is a non-hydrostatic RCM developed from the weather prediction model Local Model of the German Weather Service (DWD) (Böhm et al., 2006). It has been used for present-day simulations and future climate projections in different regions (e.g. Christensen and Christensen, 2007; Jaeger et al., 2008; Rockel and Geyer, 2008) and can simulate the modern Asian monsoon precipitation pattern well compared to other RCMs (e.g. Rockel and Geyer, 2008; Dobler and Ahrens, 2010). In this study, we use the official model version CCLM 3.2 (available at: http://www. clm-community.eu), which has been evaluated and used for the CLM consortial runs (Hollweg et al., 2008). The model has a rotated geographical coordinate system with the vertical domain represented by a terrain-following hybrid coordinate ( $\eta$ coordinate). For our experiments, we choose the leapfrog numerics (Skamarock and Klemp, 1992), the Tiedtke convection scheme (Tiedtke, 1989), the prognostic turbulent kinetic energy closure (Raschendorfer, 2001) and the TERRA-ML multi-layer soil model (Schrodin and Heise, 2002). More details on the model dynamics and physics are described in the original documentations (Doms and Schattler, 2002; Doms et al., 2007).

\subsection{Initial and lateral boundary forcing}

As the initial and lateral boundary forcing for our regional model experiments, we use 6-hourly output from a present-day control run and a Tortonian run performed in the AOGCM COSMOS (Eronen et al., 2009; Micheels et al., 2011). These experiments with the global model are referred to as GCTRL and GTORT. The resolution of the spectral atmosphere general circulation model ECHAM5 is T31 $\left(3.75^{\circ} \times 3.75^{\circ}\right)$ with 19 terrain-following vertical layers. The ocean circulation model MPIOM uses an Arakawa C-grid with an approximate resolution of $3^{\circ} \times 3^{\circ}$ and the vertical domain is represented by 40 unevenly spaced levels. The setup design of GTORT is largely based on studies for the Late Miocene using the model version ECHAM4 coupled to a slab ocean model (Steppuhn et al., 2006, 2007; Micheels et al., 2007) (see also Table 1). Atmospheric $\mathrm{CO}_{2}$ of GTORT is $360 \mathrm{ppm}$, which is the same as in GCTRL but also feasible for the Late Miocene (e.g. Pearson and Palmer, 2000; Micheels et al., 2009a). The orbital configuration also refers to the present-day situation because we aim at representing the Tortonian as an average over 4 million years. Owing 
to the coarse model resolution, the palaeogeography is almost the same as today, but the Paratethys is included (based on Popov et al., 2004; Harzhauser and Piller, 2007) and the Panama Isthmus is open with a depth of $500 \mathrm{~m}$ (based on Collins et al., 1996). Australia is moved two grid cells southward (based on Herold et al., 2008), leading to a slight opening of the Indonesian seaway. The palaeorography is reduced globally but with regional differences. Greenland has a much lower surface elevation than today in GTORT, which is due to the absence of an ice sheet in the Late Miocene. The Alps are reduced to about $70 \%$ of their modern height. The overall elevation of Tibet is also about $70 \%$ of its present-day height (Fig. 1). Finally, the surface parameters of the global model are prescribed according to a Tortonian vegetation reconstruction based on palaeobotanical data (Micheels et al., 2007, 2011). In the model, the Late Miocene is characterized by less desert and more forest cover than today. For instance, boreal forest in GTORT covers the northern high latitudes where there is tundra at present, and the vegetation of North Africa is grassland to savanna instead of the modern Sahara desert.

For each run, the AOGCM COSMOS is integrated over $2500 \mathrm{yr}$ so that the model runs are in their dynamic equilibria. Using the set of adapted Late Miocene boundary conditions, GTORT demonstrates a generally warmer $\left(+1.5^{\circ} \mathrm{C}\right)$ global condition compared to GCTRL. Global precipitation increases by $+43 \mathrm{~mm} \mathrm{a}^{-1}$ in GTORT due to the higher moisture loading in the atmosphere as a result of the higher surface temperature and greater evaporation over the ocean. Figure 2 illustrates the spatial distribution of the mean annual temperature and precipitation anomalies between GTORT and GCTRL. Primarily, higher latitudes are warmer than at present (Fig. 2a) and, hence, the meridional temperature gradient is slightly weaker in GTORT (Micheels et al., 2011). As a result of the open Panama Isthmus in GTORT, the northward heat transport in the Atlantic Ocean is weaker than in GCTRL, which is consistent with other Miocene model experiments with an open Central American Isthmus (e.g. Mikolajewicz and Crowley , 1997). The reduced ocean heat transport explains the cooling in northern Europe (Fig. 2a). This is in agreement with Steppuhn et al. (2006), who demonstrate a cooling in Europe in a Tortonian model experiment resulting from a prescribed weaker ocean heat transport. Compensating for the weak ocean circulation, the westerlies intensify in GTORT (Fig. 2c, d). This is equivalent to an increased advection of moisture and enhanced stormtracks (Micheels et al., 2011), hence, increased precipitation in Europe (Fig. 2b) in GTORT compared to GCTRL. The presence of the Paratethys leads to a cooling trend (in summer) and increased rainfall nearby. North Africa gets significantly warmer (Fig. 2a) and wetter (Fig. 2b) than in GCTRL. This is consistent with the results of Micheels et al. (2009b) studying the Late Miocene climate response to the appearance of the Sahara desert, and can be largely attributed to the reduced albedo and enhanced evapotranspiration of the a)

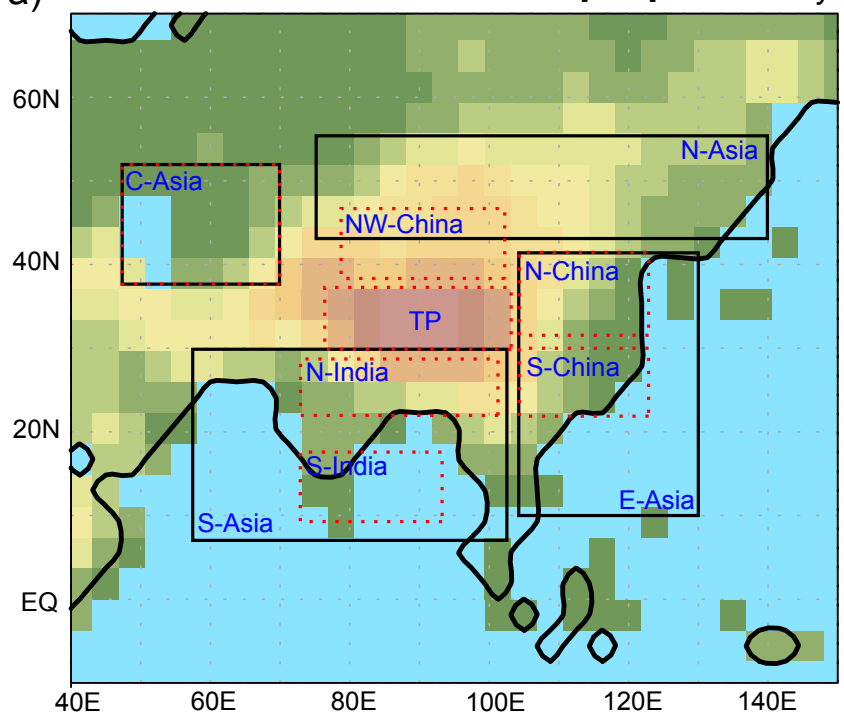

b)

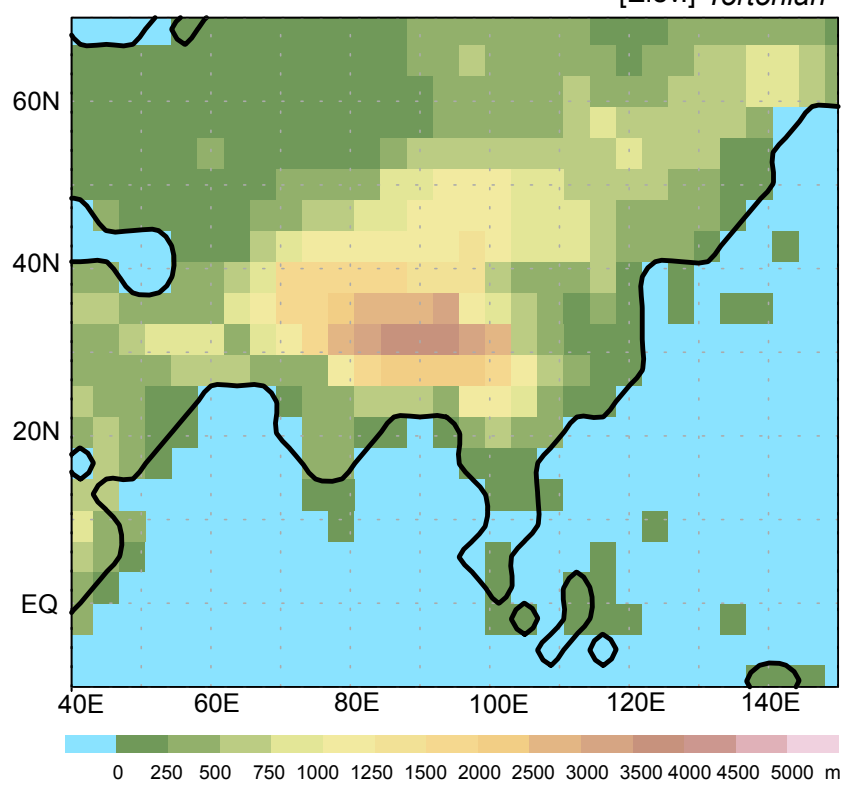

Fig. 1. The orography for the present-day control run (a) and the Tortonian run (b) of the global model. Black rectangles in (a) define the large regions referred to in the text. C-Asia: Central Asia; NAsia: North Asia; E-Asia: East Asia; S-Asia: South Asia. The regions of major interest in this study are denoted by red dotted rectangles. TP: Tibetan Plateau; N-India: northern India; S-India: southern India; NW-China: northwestern China; N-China: northern China; S-China: southern China. N-China and S-China together are referred to as E-China (eastern China).

"green" Sahara. The increase in precipitation in GTORT is most pronounced during the summer season, indicating a strong African summer monsoon.

Over the Asian monsoon area, the lowering of the TP causes a strong warming of up to more than $+10^{\circ} \mathrm{C}$. In 
a)

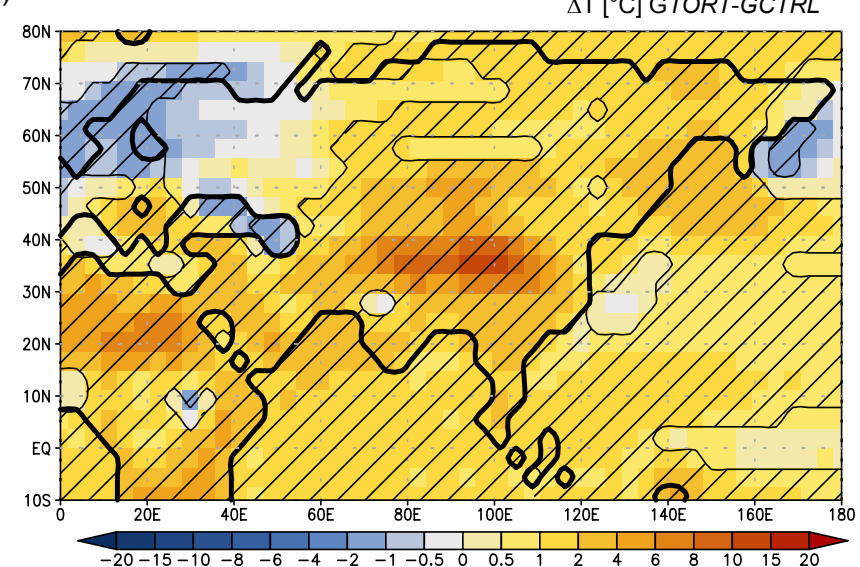

b)

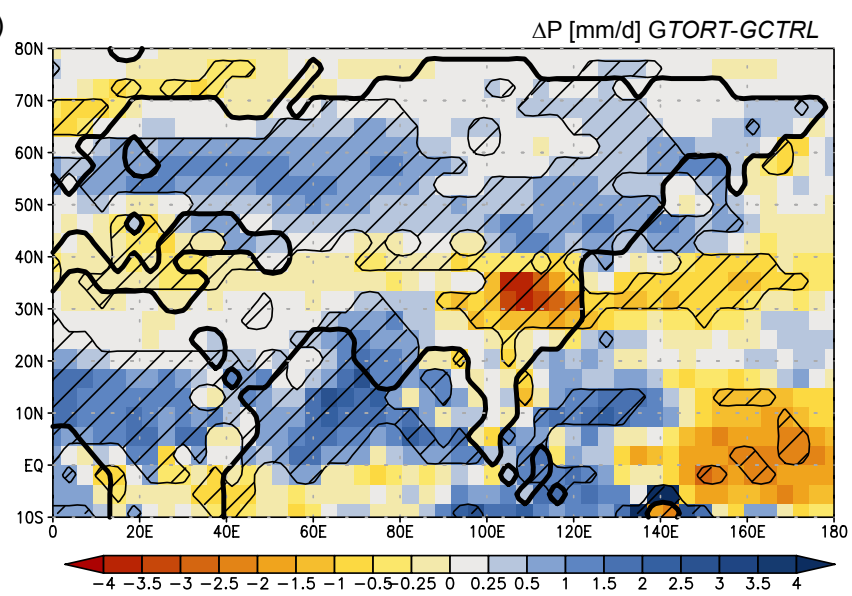

c) $850 \mathrm{hPa}$ wind GTORT-GCTRL DJF

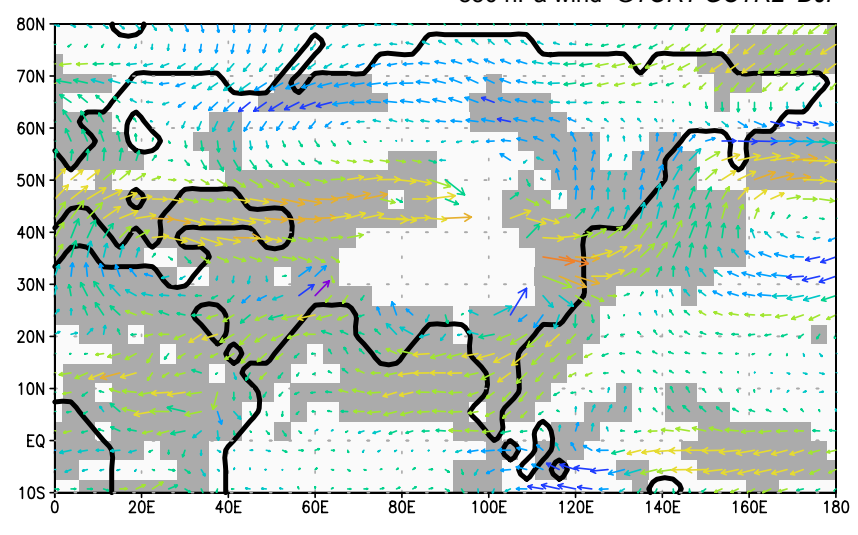

d)

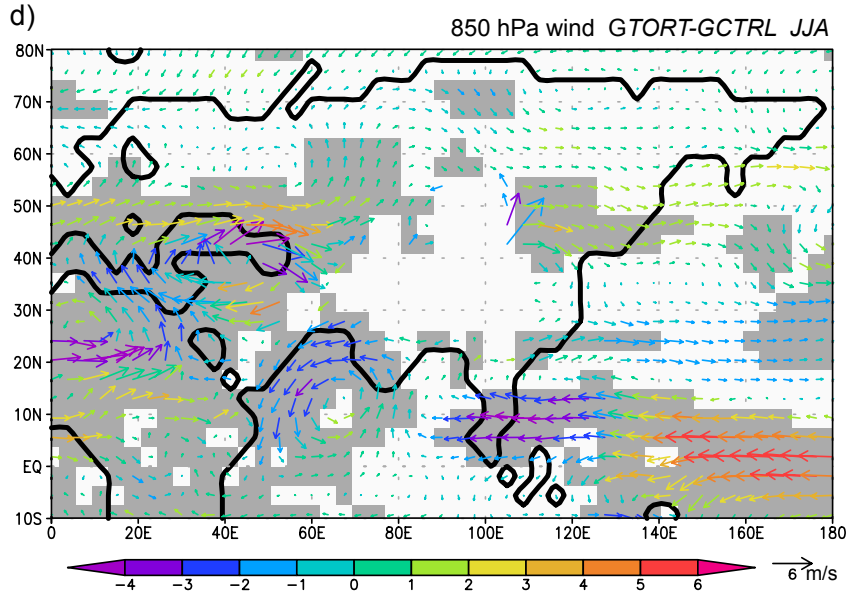

Fig. 2. The annual average difference for temperature $\left({ }^{\circ} \mathrm{C}\right)(\mathbf{a})$ and precipitation $\left(\mathrm{mm} \mathrm{d}^{-1}\right)(\mathbf{b})$, and the wind anomalies $\left(\mathrm{m} \mathrm{s}^{-1}\right)$ at $850 \mathrm{hPa}$ for winter (DJF) (c) and summer (JJA) (d) between the Tortonian (GTORT) and the present-day control (GCTRL) run of the global model. The hatched areas in (a, b) and the shaded areas in $(\mathbf{c}, \mathbf{d})$ show the significant anomalies with a Student's t-test $(p=0.05)$. The colour of vectors in (c, d) denotes the changes in wind speed.

Table 1. The setup of the Tortonian physical boundary conditions in the global model (GTORT) and the regional model (TORT). For GTORT, the boundary configurations within the regional model domain are in bold.

\begin{tabular}{|c|c|c|}
\hline Boundary conditions & GTORT & TORT \\
\hline Orography & $\begin{array}{l}\text { Tibetan Plateau (TP): } 70 \% \text { of (present-day height); } \\
\text { lower Greenland, Alps and other orography }\end{array}$ & $\begin{array}{l}\text { northern TP: } 30 \% \text { (of present-day height); } \\
\text { central and southeastern TP: } 80 \% \text {; } \\
\text { southern TP: } 100 \% \text {; } \\
\text { Tian Shan, Gobi Altai and Zagros: } 70 \% \text {; } \\
\text { other orography: } 70-90 \%\end{array}$ \\
\hline Vegetation & $\begin{array}{l}\text { northward expansion of warm forest in E-Asia and N-Asia; } \\
\text { grassland to savanna over C-Asia, W-Asia and Sahara; } \\
\text { boreal forest over the northern high latitudes including Greenland }\end{array}$ & $\begin{array}{l}\text { northward expansion of temperate deciduous forest in N-Asia; } \\
\text { grassland over C-Asia and NW-China; } \\
\text { mixed-leaf forest in the southern TP; } \\
\text { open forest in the northern TP and the Loess Plateau }\end{array}$ \\
\hline Land-sea distribution & $\begin{array}{l}\text { presence of the Paratethys and the Pannonian Lake; } \\
\text { open Panama Isthmus with a depth of } 500 \mathrm{~m} \text {; } \\
\text { southward shift of Australia and open Indonesian seaway }\end{array}$ & presence of the Paratethys with the same extent as GTORT \\
\hline$p \mathrm{CO}_{2}$ & same as GCTRL (360 ppm) & same as CTRL (360 ppm) \\
\hline Orbital parameters & present-day & present-day \\
\hline
\end{tabular}


Table 2. Summary of the regional model experiments.

\begin{tabular}{lllll}
\hline Experiments & CTRL & TORT & TORTPD & PDTORT \\
\hline Initial and lateral boundary forcings & GCTRL & GTORT & GTORT & GCTRL \\
Physical boundary conditions & present-day & Tortonian & present-day & Tortonian \\
\hline
\end{tabular}

winter, there is a clockwise wind field anomaly around the TP between GTORT and GCTRL (Fig. 2c). The northwesterly flow (i.e. the winter monsoon) over E-Asia is strengthened, while there is a stronger easterly flow in S-Asia in GTORT. Precipitation in E-China is weaker-than-present (Fig. 2b) largely due to the weaker summer monsoon circulation as a result of the impact of lower TP in GTORT (Micheels et al., 2011). The wind patterns of GTORT also represent a weaker-than-present Indian summer monsoon circulation (Fig. 2d). However, precipitation strongly increases on the Indian subcontinent (Fig. 2b), which could be misinterpreted as a strengthening of the Indian summer monsoon. Such enhanced precipitation in GTORT is primarily driven by the higher Indian Ocean surface temperature, which leads to a stronger evaporation and - although the atmospheric circulation is weaker - to a greater advection of moisture onto the Indian subcontinent (Micheels et al., 2011).

Micheels et al. (2011) compared the GTORT model results with terrestrial climate proxy data. With respect to the mean annual temperature, GTORT agrees fairly well with proxy data, but tends to be slightly too warm in lower latitudes and too cold in higher latitudes. Hence, the meridional temperature gradient in GTORT is not reduced as much as proxy data suggest. For the annual precipitation, the global model compared to proxy data demonstrates good performance, especially in central Europe and E-Asia. The model, however, tends to represent slightly more arid conditions in the Mediterranean region and the north of TP than proxy data indicate. In general, the results of GTORT show state-of-theart performance compared to other Miocene model experiments (Micheels et al., 2011). Therefore, we can use GTORT to force our regional model to simulate the climate in the Tortonian.

\subsection{Experimental design}

Our regional model domain covers the Asian monsoon area $\left(0-60^{\circ} \mathrm{N}\right.$ and $\left.50-140^{\circ} \mathrm{E}\right)$ with a spatial resolution of $1^{\circ} \times 1^{\circ}$ on the rotated model grid and 20 vertical levels. Two regional model experiments were performed first: a presentday control run (CTRL) and a Tortonian run (TORT) (Table 2). For CTRL, we use the present-day global forcing (i.e. driven by GCTRL) and the present-day physical boundary conditions (i.e. land-sea distribution, orography and vegetation) generated from WEB-PEP (version 0.74) (Smiatek et al., 2008).
For TORT, we use the Tortonian global forcing (i.e. driven by GTORT). The configurations for the Tortonian physical boundary conditions in the regional model are also summarized in Table 1. As to the palaeorography, the high spatial resolution of the regional model allows us to modify the topography in more detail than in the global model to better represent the Tortonian conditions. Although the palaeoelevation of the TP in the Tortonian remains controversial, there is growing evidence demonstrating an asynchronous surface uplift of the plateau, instead of the synchronous uplift as assumed in most of the global model studies, at that time (e.g. Molnar et al., 2010). It is shown that the southern TP may have attained its present-day height before the Tortonian (e.g. Coleman and Hodges, 1995; Rowley et al., 2001; Spicer et al., 2003). The elevation of the central and southeastern TP may have also approximated its present-day height in the Tortonin (e.g. Blisniuk et al., 2001; Rowley and Currie, 2006; Liu-Zeng et al., 2008). In contrast, the northern TP was mainly uplifted after the Tortonian, and its altitude may have been much lower in the Tortonian than at present (e.g. H. B. Zheng et al., 2000; D. W. Zheng et al., 2006; Wang et al., 2008b). To be consistent with these evidences, we keep the elevations of the Himalayas and the southern TP at their present-day heights, but reduce the central and southeastern TP to $80 \%$ and the northern TP to $30 \%$ of their present-day heights in our regional model (Fig. 3a, b). The general decrease of elevation from the south to the north of the TP agrees with the stepwise growth of the TP, such as that suggested by Tapponnier et al. (2001). For the other topographic relief in our model domain, there are limited palaeoaltimetry studies. Most of these areas have undergone both pre-Tortonian and post-Tortonian surface uplifts, such as the Tian Shan Mountains (e.g. Charreau et al., 2009) and the Zagros mountains (e.g. Lacombe et al., 2006). Therefore, we simply modify the elevations to $70-90 \%$ of their present-day heights in TORT (Fig. 3a, b). It is noted that the roughness length of orography is also reduced proportionally to its surface elevation.

The modification of vegetation in TORT is based on palaeobotanical data and consistent with the global model setup (Micheels et al., 2011). As for the topography, the regional model allows a better resolution of the vegetation in our target region. As illustrated in Fig. 3c and d, we replace the large desert area in C-Asia and NW-China by herbaceous vegetation in TORT (based on Wolfe, 1985; Sun and Zhang, 2008; Sun et al., 2009). The vegetation on the southern TP is changed to mixed leaf trees (based on Liu, 1996; 
a)

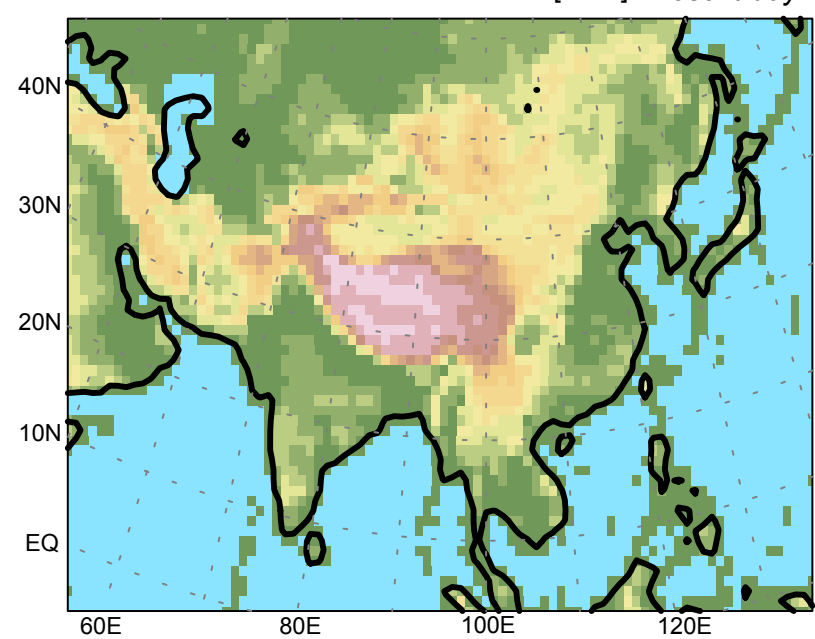

b)

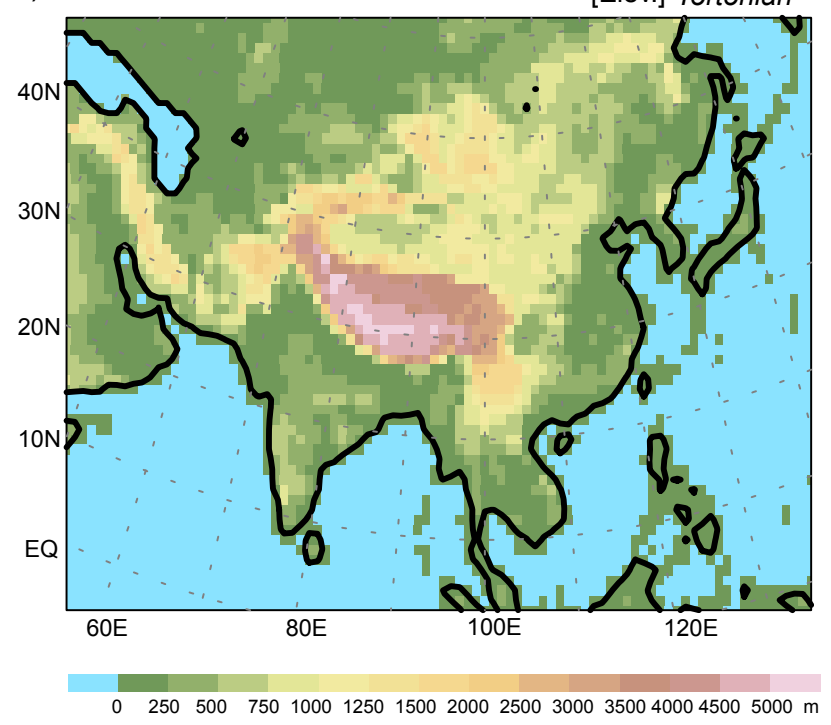

c)

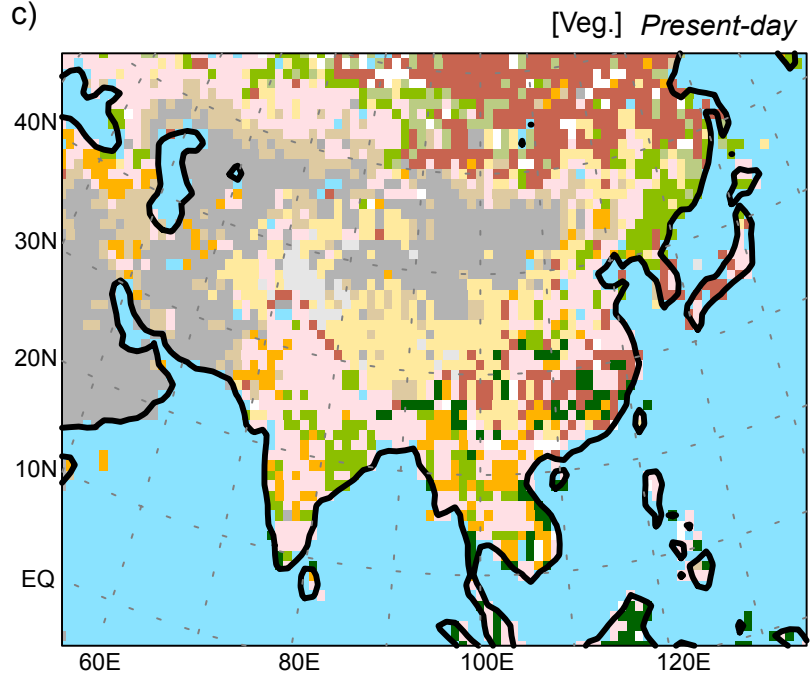

d)

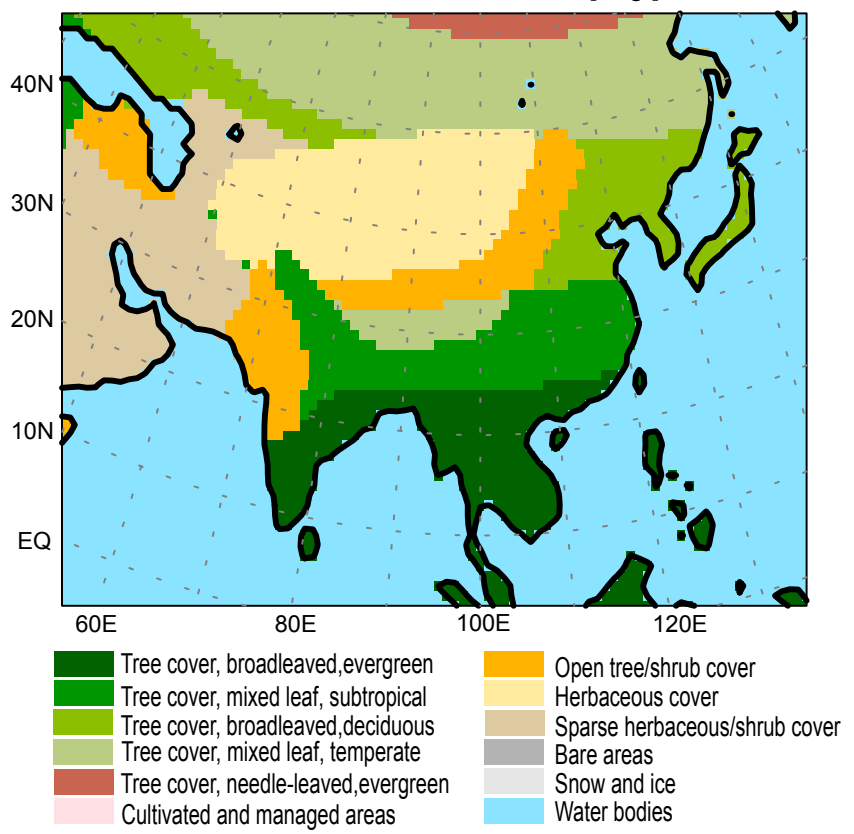

Fig. 3. The orography and vegetation for the present-day control run (CTRL) (a, c) and the Tortonian run (TORT) (b, d) of the regional model. The maps are displayed in the original rotated model grid. The present-day vegetation is based on the GLC2000 data set (http: //bioval.jrc.ec.europa.eu/) which is used in the regional model by default.

Tang and Shen, 1996). Evidence shows that the vegetation of the northern TP and the Loess Plateau underwent significant changes from forest to steppe in the Tortonian (e.g. Ma et al., 1998; Wang et al., 1999; Dong et al., 2006). Thus, we cover these areas with open forest, which acts as a transition zone between the forest in the east and the steppe in the west. E-Asia and S-Asia are dominated by forest in TORT. The range of broadleaved evergreen forest and subtropical forest is similar to their present-day potential distribution (based on Zheng and Wang, 1994; Li and Zhang, 1998; Hoorn et al., 2000; Xia et al., 2009), but the temperate deciduous forest reaches farther north (based on Liu, 1998; Wang et al., 2001; Shu et al., 2008).

The land-sea distribution in TORT is the same as in CTRL, except the presence of the Paratethys. The extent of the Paratethys resembles that in GTORT. The $p \mathrm{CO}_{2}$ is $360 \mathrm{ppm}$ for both CTRL and TORT, which is identical to our global model.

To further assess the contribution of regional topography changes (e.g. the lower TP) and global climate (e.g. the higher global surface temperature) to the Asian monsoon evolution in the Tortonian, two additional regional model 
experiments are carried out (Table 2). The first (TORTPD) uses Tortonian global forcing (TORT-GF) in combination with present-day regional boundary conditions. The second (PDTORT) uses present-day global forcing in combination with Tortonian regional boundary conditions (TORT-BC). By subtracting the climatologies of TORTPD and PDTORT by that of CTRL (i.e. TORTPD minus CTRL and PDTORT minus CTRL), the climate response to TORT-GF and TORT-BC can be obtained, respectively.

All the regional model experiments are integrated for $10 \mathrm{yr}$. Since the initial adaptation of the upper-level soil moisture requires a few months (Fig. S1 in the Supplement), the first year integration is left for the model to spin up. Only the last 9-yr results are used for analysis.

\section{Results}

\subsection{Temperature}

The mean annual surface temperature increases significantly over the ocean and most of the continent in TORT, except C-Asia and N-India (Fig. 4a). The increase of surface temperature is most pronounced in the present-day northern TP (more than $+10^{\circ} \mathrm{C}$ ), Gobi Altai and Zagros Mountains where the surface elevation is greatly reduced. In C-Asia, the lower summer temperature but higher winter temperature (Fig. 4b,c) counteract each other on annual average and result in little change of annual temperature in TORT (Fig. 4a). The insignificant change of temperature in N-India, however, persists throughout the year. Over the northern Asian continent, the increase of temperature is more pronounced in winter (Fig. 4b), indicating a reduced seasonality, while over the tropical ocean, the increase of temperature is more pronounced in summer (Fig. 4c), suggesting a enhanced seasonality of the temperature change there.

\subsection{Precipitation and evaporation}

There is a general increase of precipitation over the midlatitude areas (i.e. C-Asia and N-Asia) (especially in the winter season) and most of the Ocean (especially in the summer season) in TORT (Fig. 4d, e, f). The precipitation changes, however, show great regional difference in the monsoon regions. In S-Asia, the mean annual precipitation rate increases over the whole Arabian Sea, the western coast of India, the southern Bay of Bengal and southern Indochina, while it decreases over N-India, the northern Bay of Bengal and northern Indochina (Fig. 4d). In E-Asia, there is an enhancement of annual precipitation over the Western North Pacific (WNP) and S-China, but a decline in the northern South China Sea (SCS) and N-China (Fig. 4d). Precipitation also intensifies over the southern TP but is reduced in the presentday northern TP. All these regional differences occur mainly in the summer season (Fig. 4f).
The mean annual evaporation is enhanced in most of the inland areas such as NW-China, C-Asia and N-India in TORT, probably related to the vegetation changes (e.g. from desert to grassland) in TORT (Fig. S2a in the Supplement). The increase of evaporation is also observed over the whole Indian Ocean and the Japan Sea due to the higher sea surface temperature (SST). By contrast, evaporation is subdued greatly over the modern Caspian Sea and Black Sea owing to the presence of the Paratethys and the great drop in summer temperature. The spatial pattern of the effective precipitation (precipitation minus evaporation) anomalies between TORT and CTRL is analogous to that of the precipitation changes (Fig. S2b in the Supplement), except that the decrease of effective precipitation is more extensive due to enhanced evaporation in TORT.

\subsection{Air pressure and circulation}

In winter, there is a stronger westerly wind over C-Asia in TORT (Fig. 5a,c). The sea level high pressure centre to the northeast of TP (i.e. the Siberian-Mongolian High) is less prominent, but the low-level northwesterly flow over EChina is strengthened (Fig. 5a, c), indicating an intensified EAsian winter monsoon in TORT. The changes in circulation are also visible at the mid-troposphere, showing a generally invigorated westerly and northwesterly flow over C-Asia and E-China, but a slightly weakened westerly over the southern slope of the TP at $500 \mathrm{hPa}$ (Fig. 6a, c). In northern Eurasia, the isolines of the geopotential field at $500 \mathrm{hPa}$ shift slightly southward in TORT. The trough of the $500 \mathrm{hPa}$ to the northeast of the TP is, therefore, less pronounced. As a result, the northerly wind component in the vicinity of the trough is weakened, leading to a significant southerly wind anomaly over the Japan Sea and the surrounding areas (Fig. 6a, c).

In summer, a stronger westerly wind still prevails over C-Asia and N-Asia in TORT (Fig. 5b, d and 6b, d). The sea level low pressure center over the N-Indian subcontinent is weakened (Fig. 5d). Consistently, a cyclonic wind anomaly appears around the Arabian Sea (Fig. 5d), reflecting a weaker summer monsoon wind (i.e. the southwesterly flow) over most of the Arabian Sea and the Indian subcontinent in TORT and a southward shift of the mean position of the tropical convergence zone (TCZ) (Fluteau et al., 1999). This explains the decrease of summer precipitation in the northern part of S-Asia, but the concurrent increase of precipitation in its southern part (Fig. 4f).

In E-China, there is a southward wind anomaly at $850 \mathrm{hPa}$, indicating a weakened summer monsoon in TORT (Fig. 5b, d). The significant westward wind anomaly over the SCS also suggests a reduced summer monsoon wind (i.e. the southwesterly flow) in this area (Fig. 5b, d). As delineated by the contour of $58000 \mathrm{~m}^{2} \mathrm{~s}^{-2}$ geopotential at $500 \mathrm{hPa}$ (Fig. 6d), the WNP Subtropical High, which covers the East China Sea and most of S-China in CTRL, retreats southward to the southern coast of China, and extends to the SCS and 

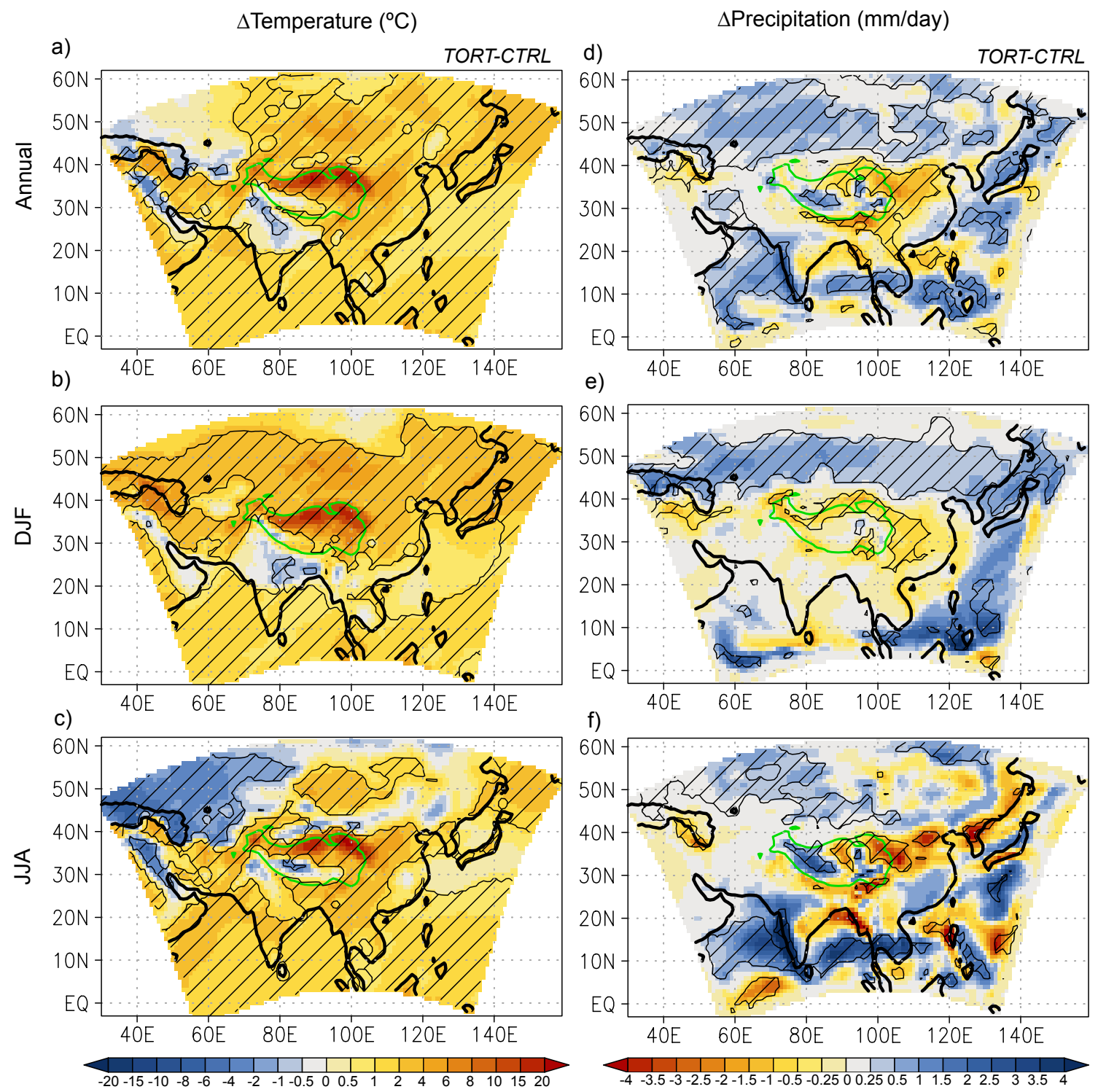

Fig. 4. Temperature $\left({ }^{\circ} \mathrm{C}\right)$ and precipitation $\left(\mathrm{mm} \mathrm{day}^{-1}\right)$ difference between TORT and CTRL. (a, d) Annual, (b, e) winter (DJF), (c, f) summer (JJA). The hatched areas show the significant anomalies with a Student's t-test $(p=0.05)$. The green contour denotes the extent of the present-day Tibetan Plateau $(>3000 \mathrm{~m})$. Note that the sponge layer (the outermost 8 grid cells) of the regional model domain is kept in the figures.

the Philippine Sea in TORT. The anticyclonic flow associated with the WNP Subtropical High (Fig. 6b) also shifts southward, which explains the significant anticyclonic wind anomaly at both $500 \mathrm{hPa}$ and $850 \mathrm{hPa}$ over the SCS and the southern coast of China (Fig. 5d and 6d).

The distribution of summer precipitation in E-Asia is closely related to the position and strength of the WNP Subtropical High (e.g. Liu et al., 2008; Chang et al., 2000). The summer rain belts are usually located in the southern flank (i.e. the WNP monsoon trough or WNP tropical convergence zone) and the northern flank (i.e. the subtropical front, which is referred to as Mei-yu front in the early summer in China) of the WNP Subtropical High. In contrast, the area dominated by the WNP Subtropical High is relatively dry. The southward displacement of the WNP Subtropical High (Fig. 6d) and the associated rain belts accounts for increased summer precipitation in S-China but reduced precipitation in N-China and the northern SCS in TORT (Fig. 4f).

\subsection{Köppen classification}

To further examine the changes of the monsoon climate regime in the Tortonian, we apply the Köppen climate classification (Kottek et al., 2006) to the output of TORT. The 


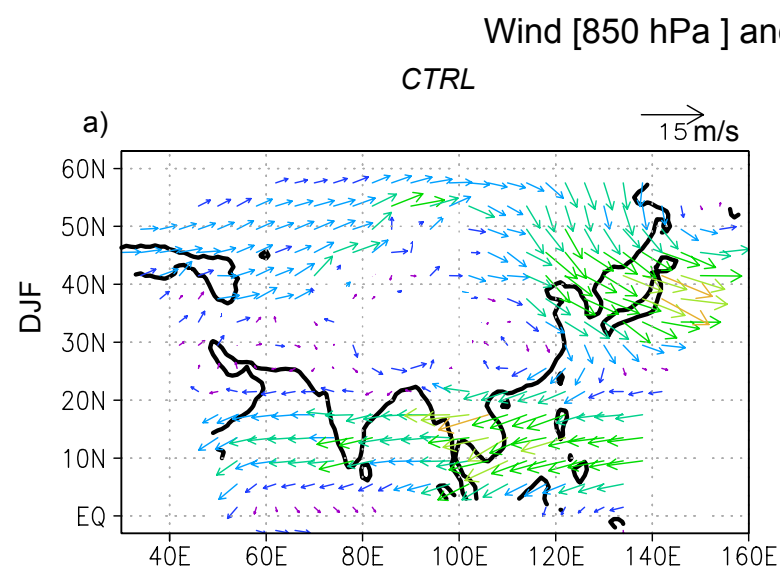

b)

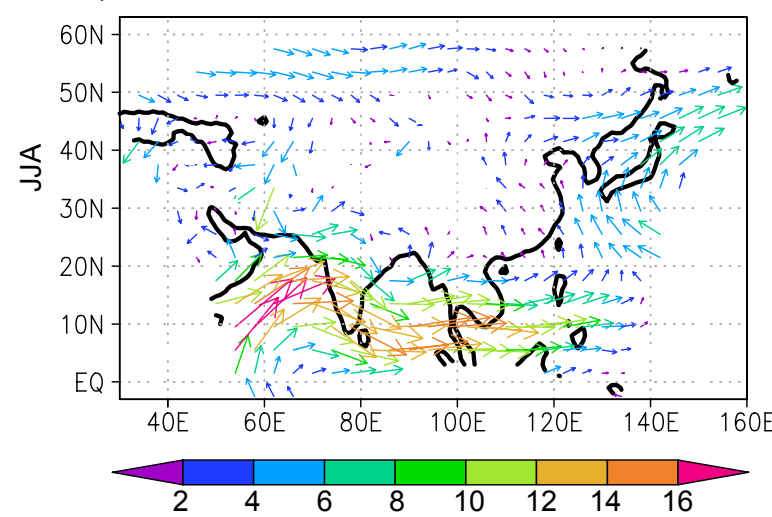

d)
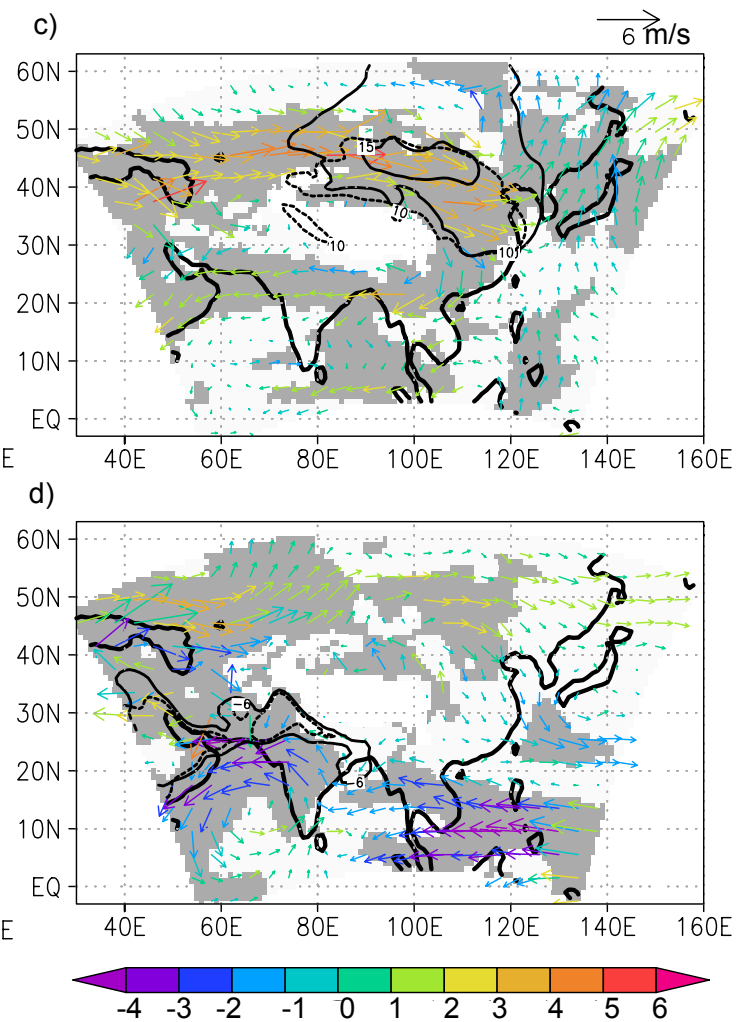

Fig. 5. Winter (DJF) and summer (JJA) wind $\left(\mathrm{m} \mathrm{s}^{-1}\right)$ at $850 \mathrm{hPa}$. (a, b) CTRL, (c, d) difference between TORT and CTRL. The grey shaded areas in $(\mathbf{c}, \mathbf{d})$ indicate the regions where either the zonal or the meridional wind anomalies are significant with a Student's t-test $(p=0.05)$. The contour lines represent the sea level pressure (hPa) anomalies to the domain average in CTRL (solid) and TORT (dashed). The colour of vectors denotes the absolute wind speed in $(\mathbf{a}, \mathbf{b})$ and the difference of wind speed in $(\mathbf{c}, \mathbf{d})$.

results are illustrated in Fig. 7. In N-China, there is an expansion of steppe climate (BS), replacing the winter dry climate $(\mathrm{Dw})$ of today, due to the great decrease of precipitation but increase of temperature in TORT. The desert climate (BW) in NW-China does not reach as far to the eastern Inner Mongolia as at present, but extends south- and southeastward to the present-day northern TP and the western part of the Loess Plateau. In contrast, the desert climate (BW) in C-Asia shrinks greatly in TORT, replaced by the summer dry (Ds) and steppe (BS) climates. This results from the increased precipitation (particularly the winter precipitation) in this area. In S-China, a large portion of the fullyhumid climate $(\mathrm{Cf})$ of the present disappears and becomes the winter dry climate $(\mathrm{Cw})$, reflecting a stronger seasonality in TORT. The dominance of winter dry climates (Aw and $\mathrm{Cw}$ ) in S-Asia and S-China implies that the monsoonal climate may have existed in the Tortonian and may have been even stronger than at present in these areas. Meanwhile, the monsoonal climate (as indicated by Dw) in N-China was still weak, and may not have been fully established yet in the Tortonian.

\section{Discussion}

\subsection{Comparison with GTORT}

The annual temperature changes in TORT are quite similar to those in GTORT (cf. Fig. 2a and Fig. 4a), depicting an extensive warmer condition in the Tortonian, but little change or slight cooling in C-Asia, N-India and the East China Sea. The changes of precipitation, however, exhibit larger spatial difference in TORT than in GTORT (cf. Fig. 2b and Fig. 4d), even though the large-scale trends of both experiments are consistent (Table 3). There is an out-of-phase change of precipitation between N-China and S-China, between S-India and N-India and also between the present-day southern and northern TP in TORT, while there is only a generally decreased precipitation over E-China and increased precipitation over all of India in GTORT. Little change of precipitation over TP is present in GTORT.

Such a difference between TORT and GTORT does not reside in the horizontal wind field, which shows good agreement between the two experiments (cf. Figs. 2c, d and 5c, 
Wind and Geopotential [500 hPa ]
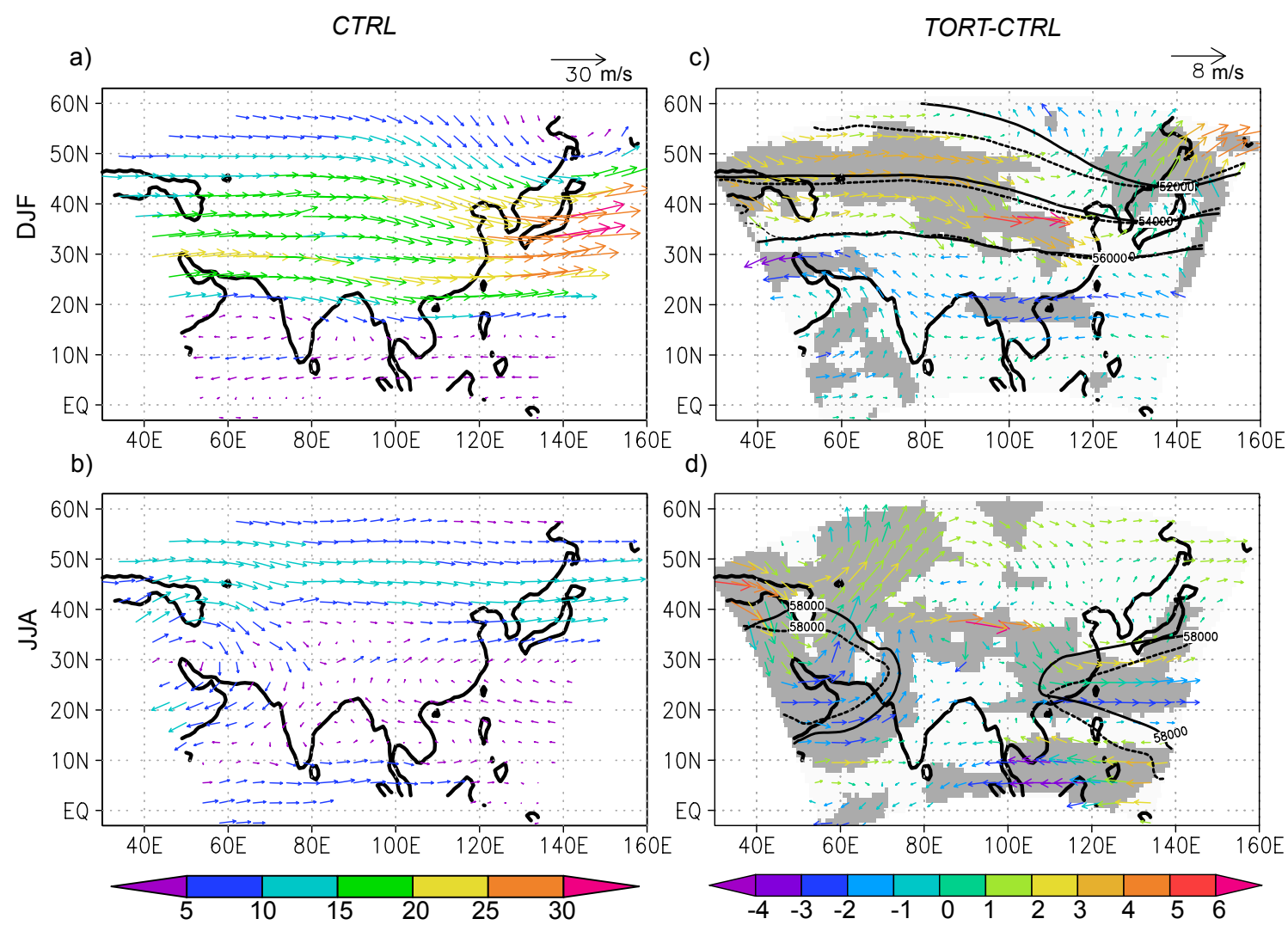

Fig. 6. Winter (DJF) and summer (JJA) wind $\left(\mathrm{m} \mathrm{s}^{-1}\right)$ at $500 \mathrm{hPa}$. (a, b) CTRL, (c, d) difference between TORT and CTRL. The grey shaded areas in $(\mathbf{c}, \mathbf{d})$ indicate the regions where either the zonal or the meridional wind anomalies are significant with a Student's t-test $(p=0.05)$. The contour lines represent the geopotential $\left(\mathrm{m}^{2} \mathrm{~s}^{-2}\right)$ in CTRL (solid) and TORT (dashed). The colour of vectors denotes the absolute wind speed in $(\mathbf{a}, \mathbf{b})$ and the difference of wind speed in $(\mathbf{c}, \mathbf{d})$.

d), but is manifested in the vertical motion. As illustrated in Fig. 8a and c, the centre of the tropical convergence zone over the Indian subcontinent and the Bay of Bengal, which is usually located at $20^{\circ} \mathrm{N}$ in the summer of present day (e.g. Goswami and Mohan, 2001; Gadgil, 2003), is well captured in our regional model but not in the global model. The rising motion is broadly strengthened over the Bay of Bengal and the Indian subcontinent in GTORT (Fig. 8c, d). In contrast, TORT exhibits a weakened upward motion at $20^{\circ} \mathrm{N}$, but a slightly intensified rising motion at $10^{\circ} \mathrm{N}$ (Fig. 8a, b). There is a generally weakened ascending motion over the TP in GTORT (Fig. 8c, d), while a strengthened rising motion over the southern TP is found in TORT, with a sinking motion enhanced immediately to the south of it and appearing in the upper troposphere over the northern TP as an offset (Fig. 8a, b). A finer structure of the changes in vertical motion is also observed to the north of the TP in TORT, such as the enhanced stormtracks at $50^{\circ} \mathrm{N}$ and the reduced topographyforced rising motion over the Tian Shan Mountains (Fig. 8a, b), all of which are missing in GTORT (Fig. 8c, d). These distinctions in vertical wind velocity are closely linked to the convection and the topography represented in the models. The better description of the regional structure of the vertical motion and precipitation in TORT, hence, demonstrates the importance of using high-resolution models in characterizing the climate changes over the Asian monsoon region.

\subsection{Comparison with monsoon proxies}

\subsubsection{Winter monsoon}

Both TORT and GTORT display a stronger-than-present EAsian winter monsoon wind (cf. Fig. 2c and Fig. 5c). This is mainly associated with the changes in the planetary scale westerly flow rather than the regional scale surface pressure gradient between the Asian continent and the North Pacific, which is weakened in both TORT and GTORT (see MO in Table 3) and would actually favour a weaker E-Asian winter monsoon wind. The importance of the westerlies in maintaining a strong winter monsoon wind in both GTORT and TORT agrees with the studies by Ding et al. (1999) and Sun (2004), which emphasize the relevance of westerlies for dust 


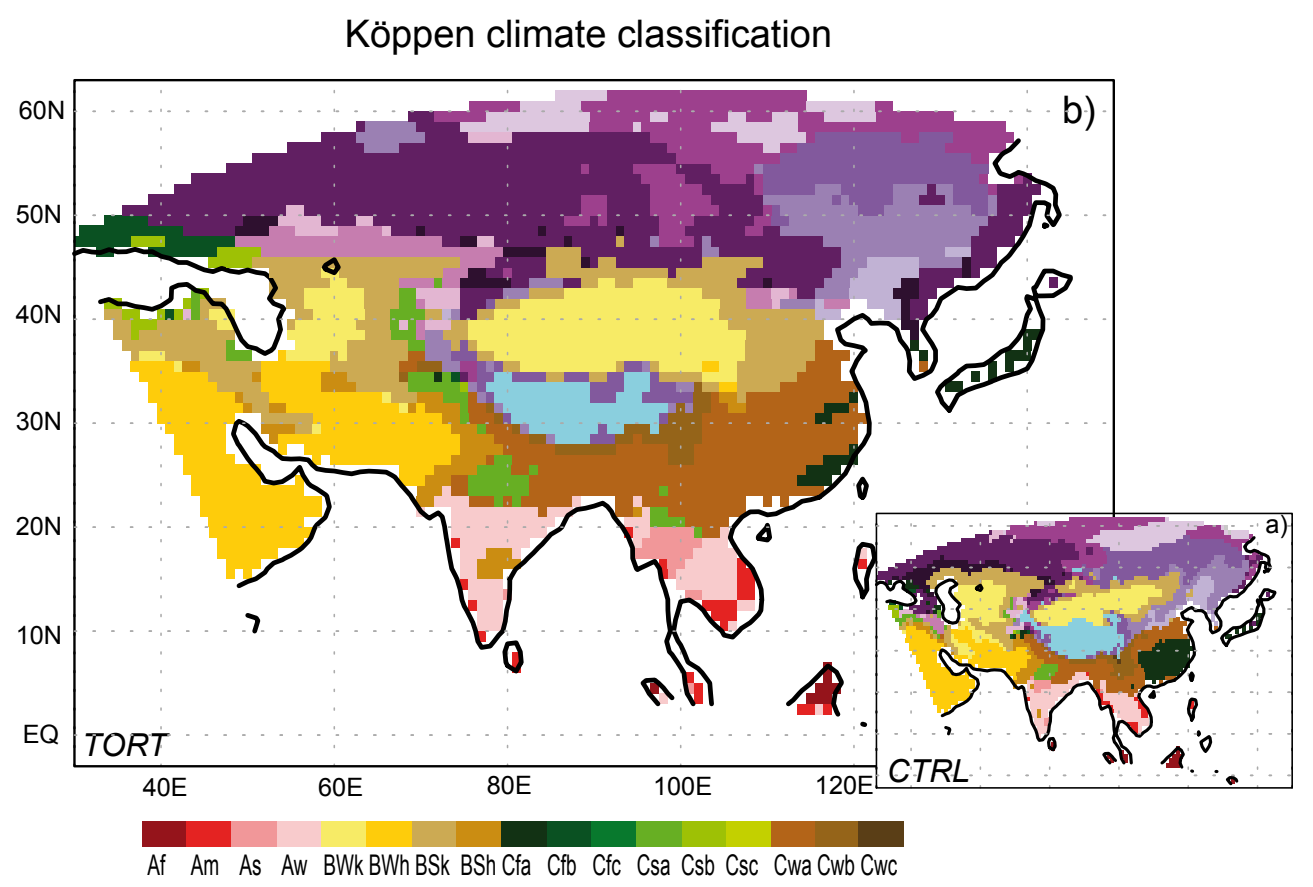

Af Am As Aw BWkBWh BSk BSh Cfa Cfb Cfc Csa Csb Csc Cwa Cwb Cwc

Dfa Dfb Dfc Dfd Dsa Dsb Dsc Dsd Dwa Dwb Dwc Dwd EF ET

\begin{tabular}{|l|l|l|}
\hline Main climates & Precipitation & Temperature \\
\hline A: equatorial & W: desert & h: hot arid F: frost \\
B: arid & S: steppe & k: cold arid T: tundra \\
C: warm temperate & f: fully humid & a: hot summer \\
D: snow & s: summer dry & b: warm summer \\
E: polar & w: winter dry & c: cool summer \\
& m: monsoonal & d:cold summer \\
\hline
\end{tabular}

Fig. 7. The Köppen-Geiger climate classification. (a) the present-day (CTRL), (b) the Tortonian (TORT). For the present-day classification, the temperature fields are derived from CRU TS 2.1 data set (Mitchell and Jones, 2005). The precipitation fields are derived from GPCC VASClimOv1.1 data set (Beck et al., 2005). To generate a similar data set for the Tortonian classification, the anomalies of the temperature and precipitation between the regional model experiments TORT and CTRL are added to the present-day observation data set.

transport and deposition on the Loess Plateau in the Late Miocene.

However, the stronger-than-present E-Asian winter monsoon wind in TORT and GTORT seems to be at odds with all the relevant proxies of this period (e.g. Rea et al., 1998; Guo et al., 2002; Jia et al., 2003; Wan et al., 2007). There was low dust accumulation rate over the western Loess Plateau (Fig. 9a), the North Pacific (with also the finer grain size of dust) (Fig. 9b) and low black carbon accumulation rate over the northern SCS (Fig. 9c) in the Tortonian. This suggests that the E-Asian winter monsoon, the agent for dust transportation, was significantly weak in the Tortonian. Similar results can also be inferred by the lack of deposition of the wind origin "Red Clay" on the central Loess Plateau before 8-7 Ma (e.g. Sun et al., 1998; Qiang et al., 2001; Zhu et al., 2008).

The accumulation rate of the dust, which most of the winter monsoon proxies rely on, is not only governed by the strength of the winter monsoon wind but also affected by the supply of the dust (Rea et al., 1998; Jia et al., 2003). Our results indicate an intensified mid-latitude precipitation, particularly in winter time (Fig. 4e), and an alleviated arid condition between $40^{\circ} \mathrm{N}-50^{\circ} \mathrm{N}$ of the Asian continent in the Tortonian (Fig. 7b). This may have suppressed the dust supply and led to the low dust accumulation rate and grain size found in the ODP site $885 / 886\left(44.7^{\circ} \mathrm{N}, 168.3^{\circ} \mathrm{W}\right)$ from North Pacific (Fig. 9b). On the other hand, the Loess Plateau, from which most of the dust records were retrieved, was mainly covered by desert or dry steppe in the Tortonian (Fig. 7b). This may have facilitated the mobilization of the dust more than the capture of the dust (e.g. the wet deposition) (Fortelius et al., 2002; Yue et al., 2009) and, hence, may have resulted in the low dust deposition rate at that time. As indicated by our model result, the surface conditions (e.g. the vegetation) probably played a more important role than the winter monsoon wind in controlling the dust accumulation in the Tortonian. 
Table 3. The comparison of annual precipitation $\left(\mathrm{mm} \mathrm{day}^{-1}\right)$, winter and summer monsoon indices between the global and regional model experiments.

\begin{tabular}{lrrrrrrrr}
\hline & GCTRL & GTORT & $\begin{array}{r}\text { GTORT- } \\
\text { GCTRL }\end{array}$ & CTRL & TORT & $\begin{array}{r}\text { TORT- } \\
\text { CTRL }\end{array}$ & $\begin{array}{r}\text { TORTPD- } \\
\text { CTRL }\end{array}$ & $\begin{array}{r}\text { PDTORT- } \\
\text { CTRL }\end{array}$ \\
\hline \multicolumn{2}{l}{ Annual Precipitation } & & & & & & & \\
\hline Domain & 2.97 & 3.21 & 0.23 & 1.98 & 2.14 & 0.16 & 0.20 & 0.01 \\
Land & 2.13 & 2.16 & 0.03 & 1.53 & 1.56 & 0.03 & 0.09 & -0.01 \\
Sea & 4.58 & 5.19 & 0.62 & 2.84 & 3.24 & 0.40 & 0.42 & 0.05 \\
\hline Winter monsoon indices & & & & & & & \\
\hline MO $^{\mathrm{a}}$ & 25.58 & 20.84 & -4.74 & 19.57 & 14.25 & -5.32 & -4.25 & -0.57 \\
WJ $^{\mathrm{l}}$ & 8.74 & 9.95 & 1.21 & 9.47 & 10.51 & 1.04 & 0.67 & 0.49 \\
\hline Summer monsoon indices $^{2}$ & & & & & & & \\
\hline EIMR $^{\mathrm{c}}$ & 858.53 & 1031.53 & 172.99 & 552.62 & 628.88 & 76.25 & 121.30 & -13.74 \\
WY $^{\mathrm{d}}$ & 26.20 & 24.07 & -2.12 & 25.92 & 23.19 & -2.73 & -1.85 & -0.34 \\
SWI $^{\mathrm{e}}$ & 1.86 & 1.98 & 0.12 & 1.58 & 1.01 & -0.56 & -0.03 & -0.43 \\
SWII $^{\mathrm{f}}$ & 0.40 & 1.21 & 0.82 & 0.27 & 0.84 & 0.57 & 0.67 & 0.18 \\
\hline
\end{tabular}

\begin{abstract}
a MO: DJF sea level pressure difference between two grid points of $\left(106.1^{\circ} \mathrm{E}, 52.9^{\circ} \mathrm{N}\right)$ near Irkutsk in Russia and $\left(145.0^{\circ} \mathrm{E}, 43.6^{\circ} \mathrm{N}\right)$ near Nemuro in Japan (based on Sakai and Kawamura, 2009). This index characterizes the pressure gradient between the Siberian High over the Asian continent and the Aleutian Low over the North Pacific, which primarily governs the northwesterly winter monsoon wind in E-Asia. b WJ: DJF $850 \mathrm{hPa}$ wind speed over E-Asia (115-130 $\left.{ }^{\circ} \mathrm{E}, 25-50^{\circ} \mathrm{N}\right)$ (based on Wang and Jiang, 2004). This index describes the low-level northwesterly wind over E-China and the East China Sea, which is an important feature of the E-Asian winter monsoon. The region of averaging is modified from the original definition $\left(115-145^{\circ} \mathrm{E}, 25-50^{\circ} \mathrm{N}\right)$ in Wang and Jiang (2004) due to the restriction of our regional model domain. ${ }^{\mathrm{c}}$ EIMR: JJAS precipitation over the extended Indian region $\left(70-110^{\circ} \mathrm{E}, 10-30^{\circ} \mathrm{N}\right)$ (based on Goswami et al., 1999). This index represents the convective heating fluctuation associated with the Indian summer monsoon. $\mathrm{d}$ WY: JJA zonal wind difference between the lower troposphere at $850 \mathrm{hPa}$ and the upper troposphere at $200 \mathrm{hPa}$ over S-Asia $\left(60-110^{\circ} \mathrm{E}, 5-20^{\circ} \mathrm{N}\right)(\mathrm{based}$ on Webster et al., 1998$)$. This index depicts the strength of the large-scale tranverse summer monsoon circulation over S-Asia controlled by the thermal contrast between the Indian/Indochina subcontinent and the tropical Indian Ocean. The region of averaging is adapted from the original definition $\left(40-110^{\circ} \mathrm{E}, 0-20^{\circ} \mathrm{N}\right)$ in Webster et al. (1998) due to the restriction of our regional model domain. e,f SWI: JJA meridional wind velocity at $850 \mathrm{hPa}$ over E-China $\left(110-125^{\circ} \mathrm{E}, 20-40^{\circ} \mathrm{N}\right)$ (adapted from $I_{\mathrm{WN}}$ in Wang et al. (2008a)). SWII: JJA meridional wind difference at $850 \mathrm{hPa}$ between S-China $\left(110-125^{\circ} \mathrm{E}, 20-30^{\circ} \mathrm{N}\right)$ and $\mathrm{N}-\mathrm{China}\left(110-125^{\circ} \mathrm{E}, 30-40^{\circ} \mathrm{N}\right)$ (adapted from $I_{\mathrm{WWO}}$ in Wang et al. (2008a)). Both indices belong to the "southwest monsoon indices" in Wang et al. (2008a), which measures the strength of low-level E-Asian summer monsoon wind (i.e. southerly wind). While SWI reflects the average strength of the E-Asian summer monsoon, SWII reflects the prevailing position of the E-Asian summer monsoon system. Increase of SWII indicates a southward displacement of the monsoon system, and vice versa.
\end{abstract}

\subsubsection{E-Asian summer monsoon}

Both TORT and GTORT reveal a weaker E-Asian summer monsoon circulation than today (Fig. 2d and Fig. 5d). Such change is more associated with a southward shift of the prevailing summer monsoon system (see SWII in Table 3) than with a general weakening of the summer monsoon over EAsia (see SWI in Table 3). Owing to the weakened EAsian summer monsoon circulation, both experiments suggest a drier-than-present condition of N-China in the Tortonian (Fig. 2b and Fig. 4f). This is consistent with the hypsodonty of the fossil mammal teeth, which documents less precipitation (higher hypsodonty) in N-China in most of the Tortonian (11-8 Ma) than at present (Fortelius et al., 2002; Eronen et al., 2010b) (Fig. 10a), but contradicts the pollen studies by Jiang and Ding $(2008,2009)$ (Fig. 9d), which report a moisture condition in the Tortonian similar to or wetter than at present. Passey et al. (2009) find the expansion of $\mathrm{C}_{4}$ plants over N-China at $7 \mathrm{Ma}$ (Fig. 9e), and indentify such changes as a shift of the semi-humid climate band, which favours the growth of $\mathrm{C}_{4}$ plants (i.e. steppe forest), into $\mathrm{N}$ China. The general absence of $\mathrm{C}_{4}$ plants before $7 \mathrm{Ma}$ can be attributed to the either too dry or too humid conditions in N-China (Passey et al., 2009). Our results imply that it is probably the drier conditions that inhibited the growth of $\mathrm{C}_{4}$ plants in N-China in the Tortonian. The dominance of the arid climates over N-China in TORT (Fig. 7b) demonstrates a more zonal distributed (planetary-like) mid-latitude aridity in the Tortonian. This confirms the studies by L. P. Liu et al. (2009) and Y. S. Liu et al. (2011) based on mammal and plant fossil records, and supports the onset of summer monsoon climate in N-China in the Late Miocene (e.g. An et al., 2001) rather than the Early Miocene (e.g. Sun and Wang, 2005; Guo et al., 2008).

In S-China, both TORT and GTORT display a strengthened summer monsoon precipitation as a result of the southward shift of the prevailing E-Asian summer monsoon system. However, on an annual average, precipitation decreases in GTORT (Fig. 2b), but increases in TORT (Fig. 4d). The results of TORT are in better agreement with the chemical weathering index retrieved from the northern SCS (Fig. 9f), which reflects a stronger runoff (thus precipitation) of the drainage of the Pearl river in the Tortonian than in the subsequent periods. The higher monsoon precipitation of S-China 

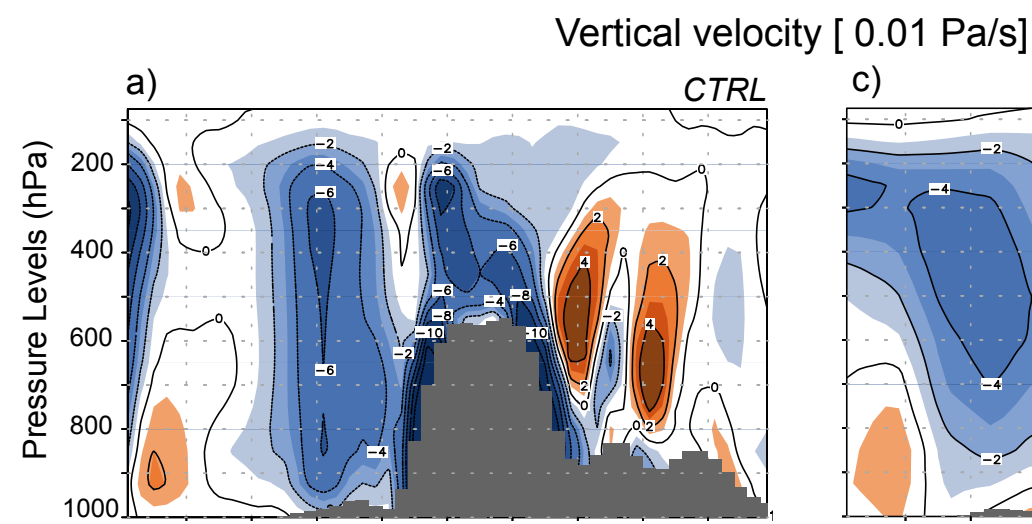

c) GCTRL
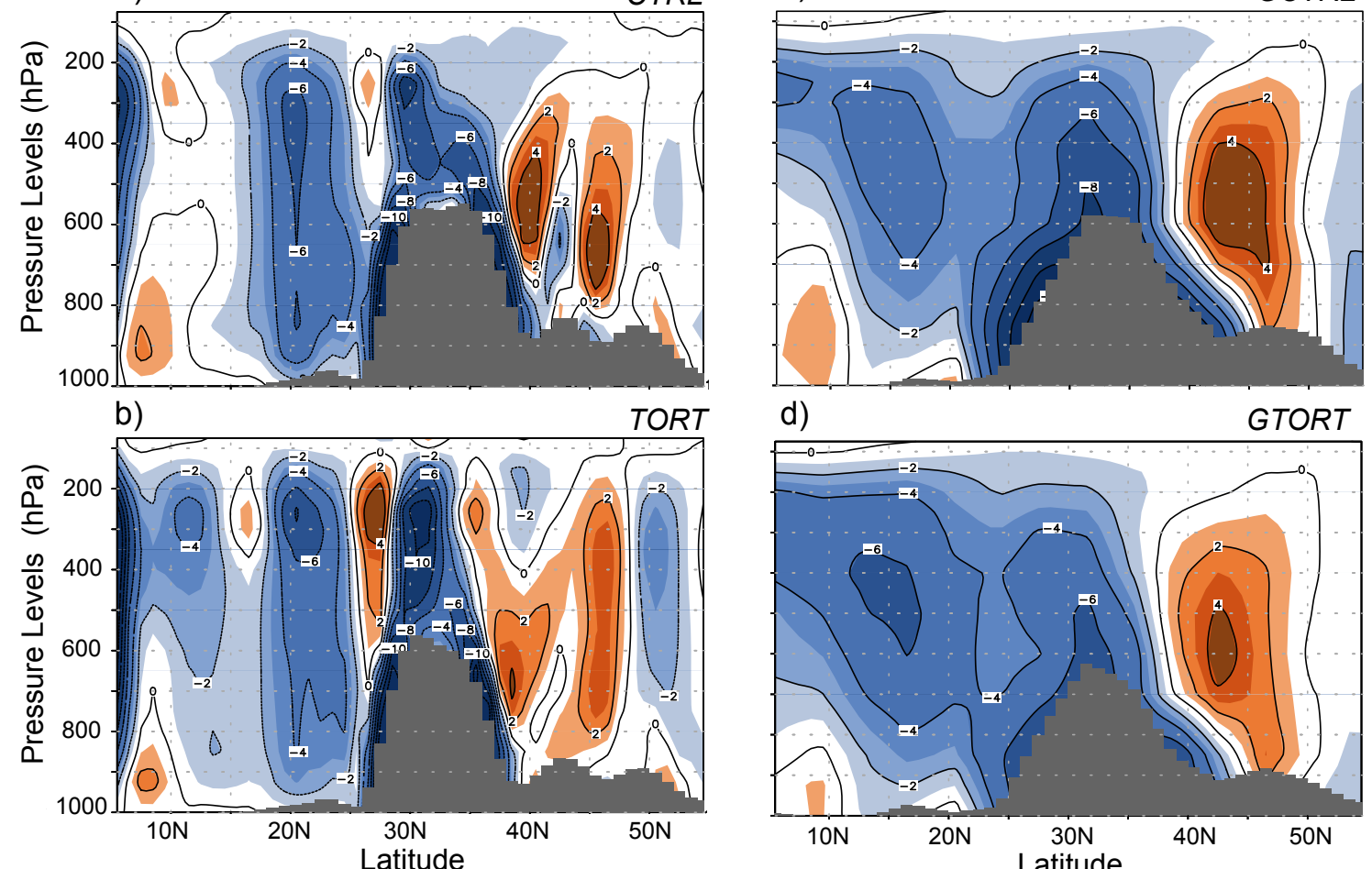

d)

GTORT

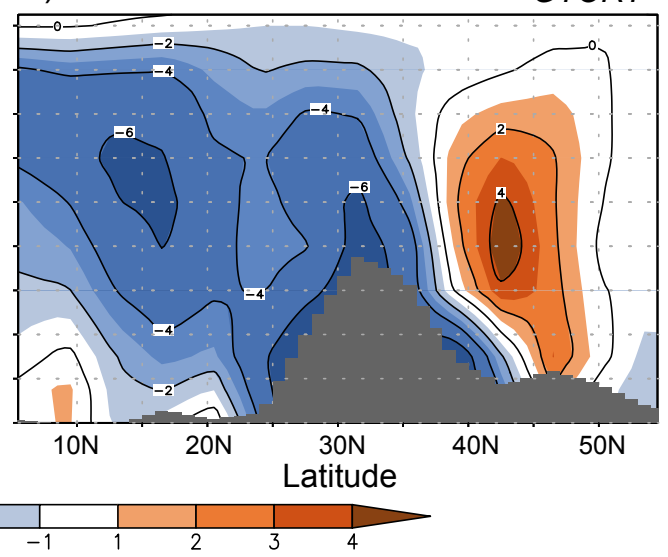

Fig. 8. Zonal averaged vertical wind velocity $\left(10^{-2} \mathrm{~Pa} \mathrm{~s}^{-1}\right)$ over longitude between $80^{\circ} \mathrm{E}$ and $95^{\circ} \mathrm{E}$ in the summer season (JJA). (a) CTRL, (b) TORT, (c) GCTRL, (d) GTORT. The blue colour denotes rising motion and the red colour denotes sinking motion. The grid cells with pressure larger than the surface pressure are shaded by dark gray colour.

has been intuitively regarded as an indication of a strong E-Asian summer monsoon in the Miocene (e.g. Clift et al., 2008; Steinke et al., 2010) (Fig. 9f), which conflicts with the weak E-Asian summer monsoon evidenced in the proxies from N-China (e.g. An et al., 2001; Fortelius et al., 2002; Passey et al., 2009) (Fig. 9e). However, as illustrated in TORT, the precipitation changes in S-China and N-China can be out of phase. In such case, a strong (weak) EAsian summer monsoon is commonly characterized by the increased (decreased) precipitation in N-China but decreased (increased) precipitation in S-China (Wang et al., 2008a). Therefore, the seemingly contradictory records from S-China and N-China in the Tortonian can be actually concordant with each other, and both point to a weak E-Asian summer monsoon at that time. There was a distinct decline of the monsoon precipitation in S-China at the end of the Tortonian (Clift et al., 2008; Steinke et al., 2010) (Fig. 9f), coinciding with the significant increase of monsoon precipitation in N-China (e.g. Fortelius et al., 2002; Kaakinen et al., 2006; Passey et al., 2009) (Fig. 9e). This further corroborates the existence of the out-of-phase precipitation changes between $\mathrm{N}$-China and S-China and provides coherent evidence for the strengthening of the E-Asian summer monsoon at 8-7 Ma.

\subsubsection{Indian summer monsoon}

Both TORT and GTORT suggest a weakened Indian summer monsoon circulation (see Fig. 2d, 5d and WY in Table 3). This agrees well with the weak summer monsoondriven upwelling over the western Arabian sea in the Tortonian (Kroon et al., 1991; Huang et al., 2007) (Fig. 9i). However, the status of the summer monsoon precipitation and the humidity over the Indian subcontinent in the Tortonian remains elusive. GTORT reveals a general strengthening of summer monsoon precipitation and a fully humid condition over the whole Indian subcontinent (see EIMR in Table 3 and Fig. 2b). This concurs with the studies on pollen assemblages (Fig. 9h) and $\delta^{18} \mathrm{O}$ of bivalve shells in Nepal (Hoorn et al., 2000; Dettman et al., 2001) and the low hypsodonty of the mammal fossil teeth (Fig. 10a). Similar results are also discovered in the record from the southern tip of the Indian Peninsula (Armstrong-Altrin et al., 2009) and manifested by the higher chemical weathering and physical erosion of the Himalayas and the foreland basins in the Tortonian (Derry and FranceLanord, 1996; Clift et al., 2008).

TORT also shows a general increase of summer monsoon precipitation on average of the whole Indian monsoon region 


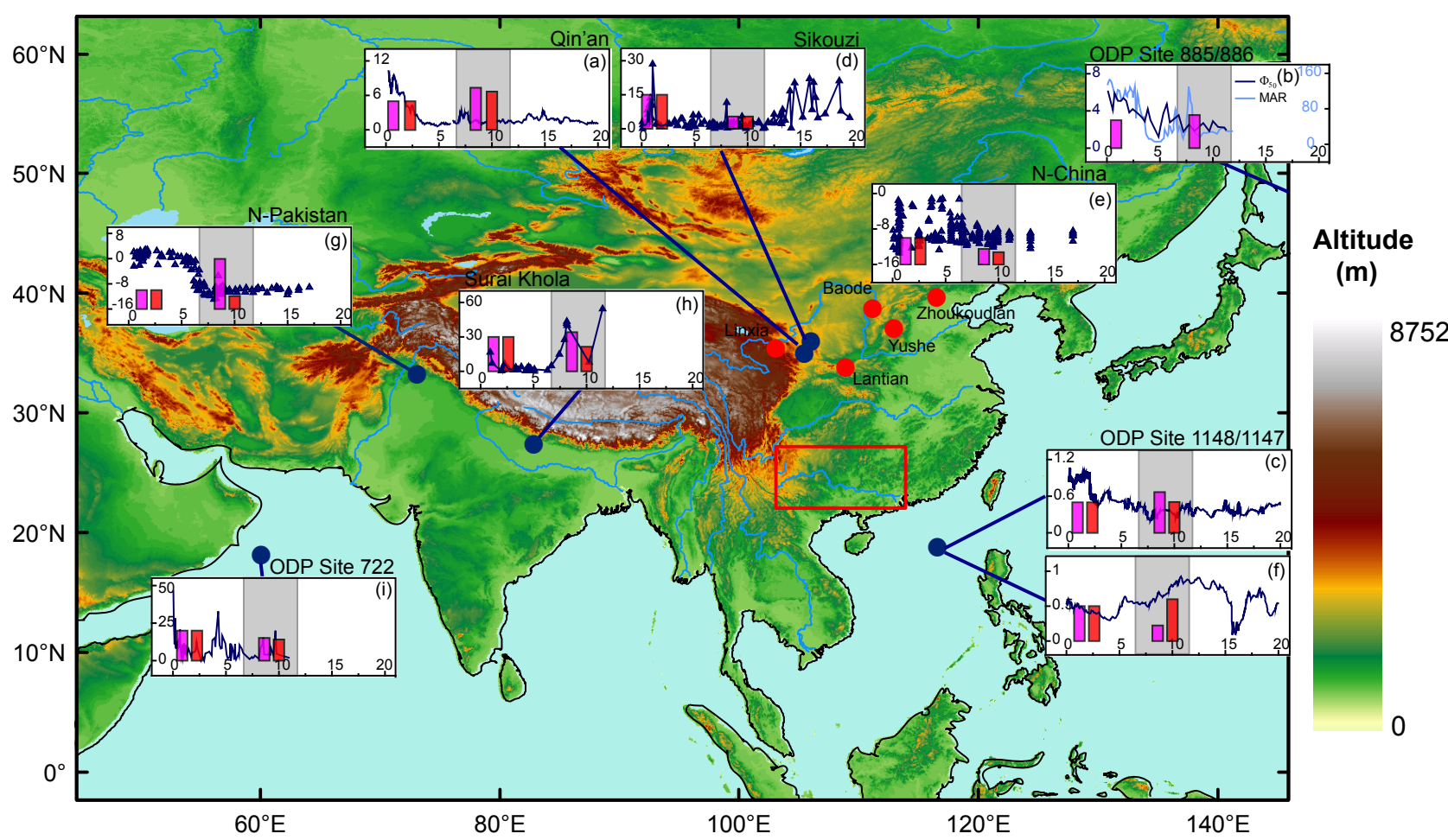

Fig. 9. Proxy records of the Asian monsoon variation in the Neogene and the comparison with the global model (purple bars - left: GCTRL; right: GTORT) and regional model (red bars - left: CTRL; right: TORT) results. (a) Dust accumulation rate (cm kyr ${ }^{-1}$ ), Loess Plateau, N-China (Guo et al., 2002); compared with the $500 \mathrm{hPa}$ wind speed (DJF) at the same locality in the model. (b) Mass accumulation rate (right axis, $\mathrm{mg} \mathrm{cm}^{-2} \mathrm{kyr}^{-1}$ ) and grain size (left axis, $\phi_{50}$ ), ODP site 885/886 (Rea et al., 1998); compared with the $500 \mathrm{hPa}$ wind speed (DJF). (c) Black carbon accumulation rate $\left(\mathrm{mg} \mathrm{cm}^{-2} \mathrm{kyr}^{-1}\right)$ ), ODP site 1147/1148 (Jia et al., 2003); compared with the $850 \mathrm{hPa}$ wind speed (DJF); (d) Humidity index, Sikouzi, N-China (Jiang and Ding, 2008); compared with the mean annual precipitation; (e) $\delta^{13} \mathrm{C}(\%$, VPBD) of tooth enamel, localities denoted by red dots, N-China (Passey et al., 2009); compared with the mean JJA-precipitation; (f) Chemical weathering index $\left(C_{\mathrm{RAT}}\right.$ ), ODP site 1148 (Clift et al., 2008); compared with the mean annual runoff over the reach of Pearl river as denoted by the red rectangle; (g) $\delta^{13} \mathrm{C}$ (\%o, PBD) of pedogenic carbonate, northern Pakistan (Quade et al., 1989); compared with the mean JJA-precipitation; (h) Quercus (\%), Central Nepal (Hoorn et al., 2000); compared with the mean annual precipitation; (i) G. Bulloides (\%), ODP site 722 (Huang et al., 2007); compared with the $850 \mathrm{hPa}$ wind speed (JJA). In all cases, the $\mathrm{x}$-axis represents the age (Ma). The light gray shaded area denotes the Tortonian (11-7 Ma). All the bars are shown in relative scale.

(see EIMR in Table 3), but the wetter conditions are confined to S-India and the southern TP (Fig. 4d). A drier condition is found in the N-Indian subcontinent. This disagrees with the proxies from C-Nepal (Hoorn et al., 2000; Dettman et al., 2001) (Fig. 9h), but is in better accordance with the $\delta^{13} \mathrm{C}$ records of the pedogenic carbonate from N-Pakistan (Fig. 9g) (Quade et al., 1989) and the western Himalayan foreland basin (Sanyal et al., 2010), which reflect a weak summer monsoon precipitation before 8-7 Ma and a striking enhancement afterwards. Note that although the summer precipitation is reduced over the N-Indian subcontinent in TORT, the Köppen classification suggests that the monsoonal climate (Cwa) may have existed in most of this area in the Tortonian (Fig. 7b). This concords with the evidence from C-Nepal (Dettman et al., 2001) and Yunnan, southwest China (Xia et al., 2009; Jacques et al., 2011). In contrast, a summer dry climate (Csa) covers the foreland basin of the western Himalayas in TORT (Fig. 7b), indicating that the emergence of the monsoonal climate of this region was probably later than the Tortonian and also later than in the rest of the Indian subcontinent. This confirms the results of Quade et al. (1989) and Sanyal et al. (2010), implying a spatial difference in the establishment of the Indian monsoon climate in the Tortonian.

\subsubsection{Aridity in C-Asia}

The relatively humid conditions of C-Asia shown in our results (Fig. 7b) are consistent with a pollen study by Sun and Zhang (2008) and the low hypsodonty of this period (Fig. 10a). In contrast, the arid conditions over NW-China are already present in the Tortonian simulation (Fig. 7b). This finding contradicts Ma et al. $(1998,2005)$ and Sun et al. (2009), who claim humid conditions in NW-China in the Tortonian and the initiation of the desert around 8-7 Ma. It is, however, in agreement with the $\delta^{18} \mathrm{O}$ records from 


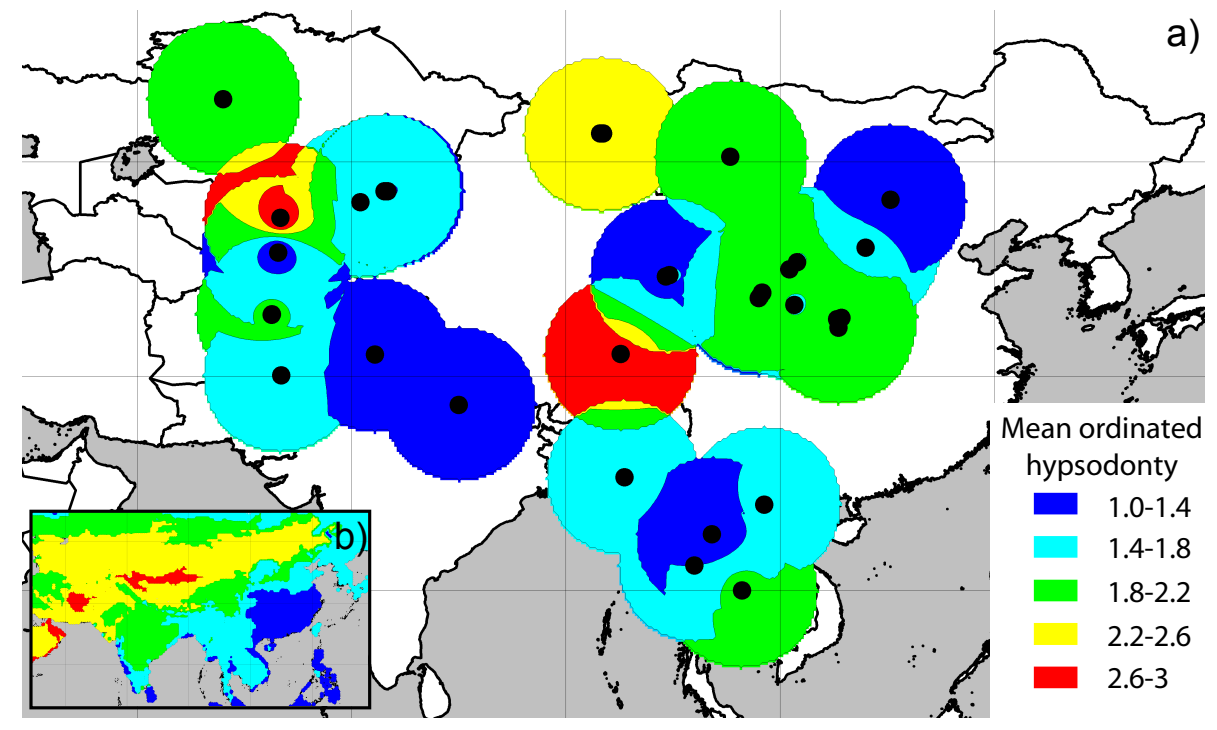

Fig. 10. The colour-interpolated map of large mammal plant-eater mean hypsodonty by fossil localities (black dots) in Asia during the early Late Miocene (11-8 Ma ) (Eronen et al., 2010b) (a) compared with the present day (Eronen et al., 2010a) (b). The higher hypsodonty indicates lower precipitation, and vice versa.

Wind [850 hPa ] and Sea level pressure
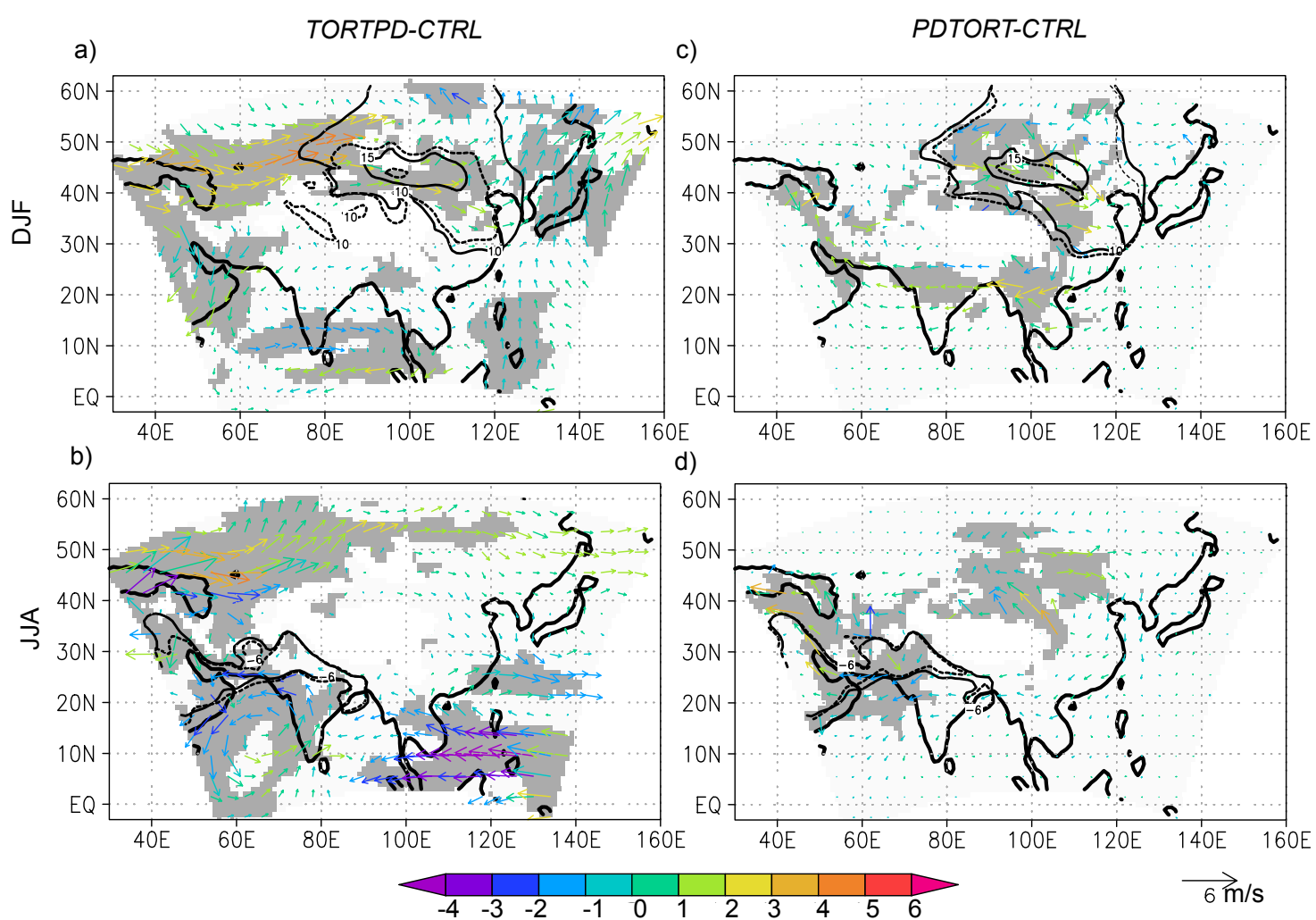

Fig. 11. $850 \mathrm{hPa}$ wind anomalies $\left(\mathrm{m} \mathrm{s}^{-1}\right)$ of TORTPD and PDTORT to the present-day control run (CTRL). (a) TORTPD minus CTRL, DJF; (b) TORTPD minus CTRL, JJA; (c) PDTORT minus CTRL, DJF; (d) PDTORT minus CTRL, JJA. The grey shaded areas show the regions where either the zonal or the meridional wind anomalies are significant with a Student's t-test $(p=0.05)$. The contour lines represent the sea level pressure anomalies to the domain average in CTRL (solid) and TORTPD or PDTORT (dashed). The colour of vectors denotes the changes in wind speed. 
Linxia Basin (Dettman et al., 2003) and the high hypsodonty (Fig. 10a), which support the presence of dry climate over NW-China already in the Tortonian.

\subsection{Influence of global forcing and regional boundary conditions}

The climate changes in TORT are the combined effect of the Tortonian global climate forcing (TORT-GF) and regional boundary conditions (TORT-BC). Disentangling the changes related to TORT-GF (i.e. TORTPD minus CTRL) and TORT-BC (i.e. PDTORT minus CTRL) would provide useful guidance to the mechanisms responsible for the monsoon changes. Owing to the fact that the regional vegetation changes have a minor impact on most of the climate variables in TORT (data no shown), the effect of TORT-BC can be simply regarded as the response to regional orographic changes (e.g. the lower northern TP). In contrast, the effect of TORT-GF is more associated with changes in the global climate system (e.g. warmer sea surface temperature), ultimately due to the boundary conditions that in part operate far beyond our regional model domain.

It is shown that the overall warmer conditions in TORT are largely due to TORT-GF (Fig. S3 in the Supplement). The contribution of TORT-BC to the warmer TORT is restricted to areas with reduced elevation. TORT-BC even has a cooling effect over N-India. This counteracts the warming effect of TORT-GF, leading to little change of temperature in this area in TORT (Fig. 4a). The warmer winter but cooler summer of C-Asia in TORT is affected by both TORT-GF and TORTBC (Fig. S3 in the Supplement), in which the presence of the Paratethys acts as a temperature buffer to its surrounding area owing to its greater heat capacity (Ramstein et al., 1997; Fluteau et al., 1999).

Both TORT-GF and TORT-BC give rise to the stronger EAsian winter monsoon wind in TORT (see WJ in Table 3). TORT-GF, however, is only responsible for the strengthening of the winter monsoon wind in N-China (Fig. 11a). This is related to the enhancement of the westerly flow over Cand N-Asia in GTORT, which is shown in Micheels et al. (2011) to be induced by the weakened meridional circulation in the North Atlantic as a result of the opening of the Panama Isthmus. By comparison, TORT-BC does not only contribute to the stronger winter monsoon wind in N-China, but also strengthens the winter monsoon wind in S-China and results in the easterly wind anomaly over N-India (Fig. 11c). This can be attributed to the effect of the lower northern TP that allows more westerly flow through the northern TP to $\mathrm{N}$-China, while diminishing the westerly flow south of the TP (Fig. 11c). The enhanced cold advection from E-China to N-India due to TORT-BC may explain the decrease of winter temperature in N-India in PDTORT (Fig. S3 in the Supplement).

TORT-GF exerts an extensive impact on both the largescale and the regional pattern of the summer monsoon in
TORT. Precipitation over most of S-Asia is intensified by TORT-GF (see EIMR in Table 3 and Fig. 12c), owing to its higher sea surface temperature of the Indian Ocean which may relate to the opening of the Indonesian seaway in GTORT (Cane and Molnar, 2001). The S-Asian and EAsian summer monsoon circulations are, however, weakened largely by TORT-GF (see WY and SWII in Table 3 and Fig. 11b), in which the dampened summer monsoon circulations are primarily ascribed to the combined effect of the lower whole TP and the presence of the Paratethys (Micheels et al., 2011) (Fig. 1). In addition, other mechanisms may also play a role, such as the grassland cover of Sahara in GTORT (Micheels et al., 2009b). It is TORT-GF which brings about the different precipitation changes between S- and N-China, and between S- and N-India in TORT (Fig. 12c). This indicates that the regional difference of the monsoon climate is intrinsic in GTORT, which is not visible in GTORT simply because of its coarse resolution.

Compared to TORT-GF, the contribution of TORT-BC to the summer monsoon changes in TORT is limited. Different from TORT-GF, which major effect is displacing the E-Asian summer monsoon system southward (see SWII in Table 3), TORT-BC weakens the summer monsoon generally over EAsia (see SWI in Table 3). There is a significant weakening of the summer monsoon wind and precipitation in N-China due to TORT-BC (Fig. 11d and 12f). This indicates a strong influence of the lower northern TP on the summer monsoon strength over N-China, which is in concert with the study by Boos and Kuang (2010). TORT-BC has little influence on the Indian summer monsoon (see EIMR and WY in Table 3 and Fig. 11d, 12f). This lends support to the idea that the southern TP alone is sufficient to maintain a summer monsoon of present-day strength in S-Asia (e.g. Boos and Kuang, 2010). There is only a small weakening of the southwesterly flow in the northwestern Indian subcontinent induced by TORT-BC (Fig. 11d). This can be attributed to the lower Zagros Mountains ( $70 \%$ of the present-day height) (Fig. 3b), allowing the intrusion of mid-latitude dry air to N-India, and delaying the seasonal onset of the summer monsoon (Chakraborty et al., 2002). TORT-BC plays an important role in the precipitation changes over the TP and the northeast of the TP (Fig. 12f), suggesting that precipitation in these areas can be highly sensitive to and indicative of regional topographic changes.

Our results emphasize the influence of both the global climate and regional tectonic changes on the monsoon evolution in the Tortonian. It was probably the combined effect of both that prevented the monsoonal climate pattern from forming in N-China in the Tortonian (Fig. 7b). This is in contrast to the model studies by Zhang et al. (2007a,b), which suggest that the transition of palaeo-environments in $\mathrm{N}$-China from a planetary-like to a monsoon-like pattern may have occurred in the early Miocene, based only on the effects of regional tectonic changes. It has been proposed that the warmer conditions over the oceans and the high-latitudes in the Late Miocene or before, would have been able to maintain a strong 

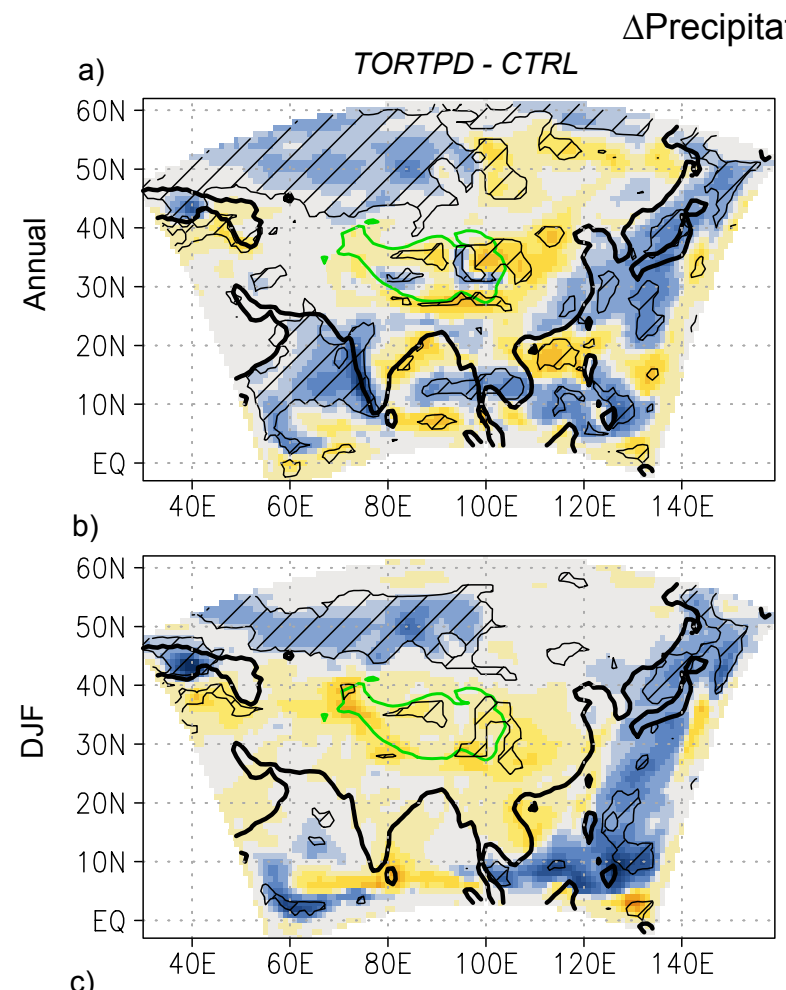

e)
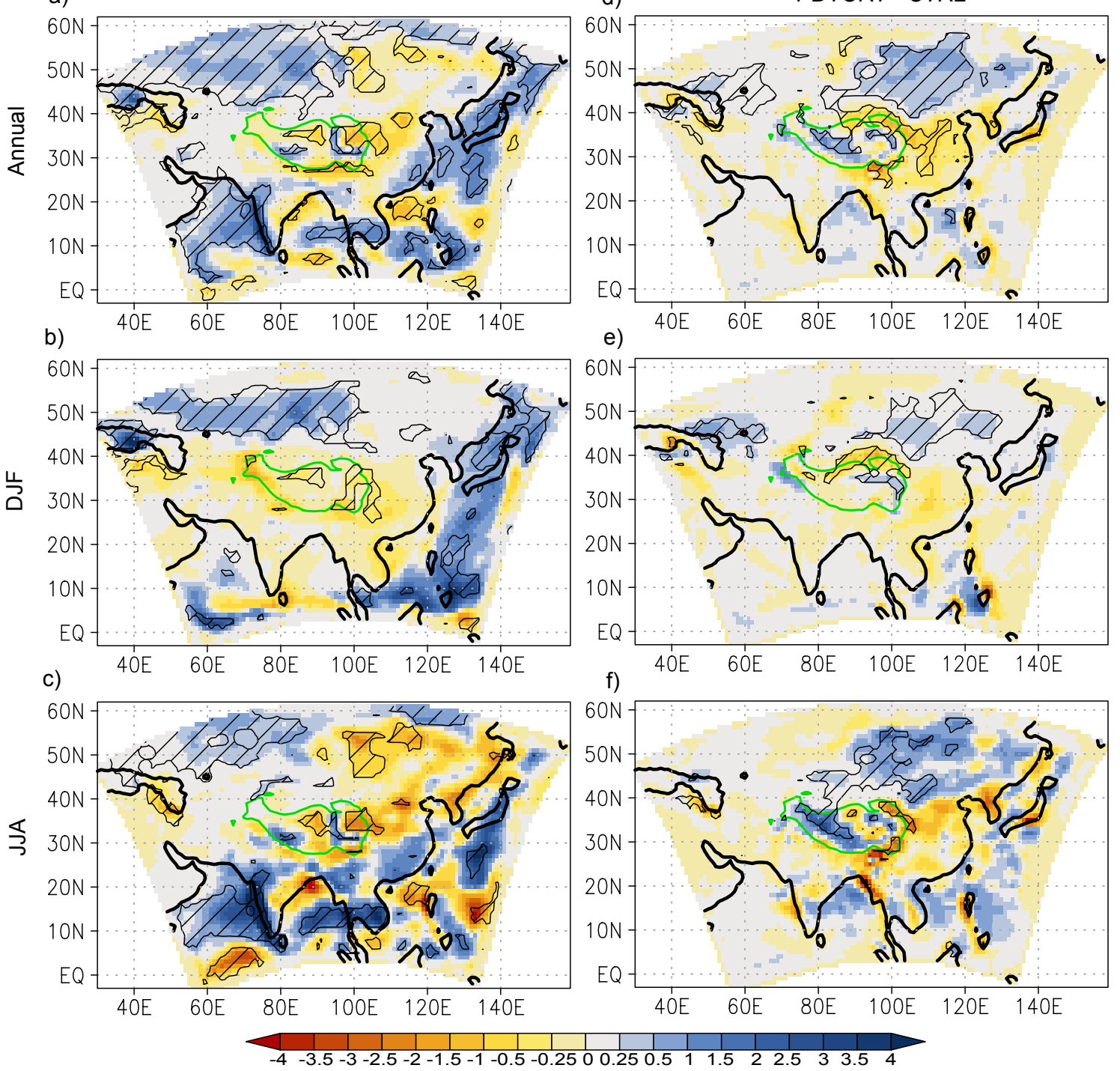

Fig. 12. Precipitation $\left(\mathrm{mm} \mathrm{day}^{-1}\right)$ anomalies of TORTPD and PDTORT to the present-day control run (CTRL). (a, b, c) TORTPD minus CTRL, (d, e, f) PDTORT minus CTRL. (a, d) Annual, (b, e) winter (DJF), (c, f) summer (JJA). The hatched areas show the significant anomalies with a Student's t-test $(p=0.05)$. The green contour denotes the extent of the present-day Tibetan Plateau ( $>3000 \mathrm{~m})$.

summer monsoon (precipitation), while the TP may have played a secondary role, supposing it had been uplifted to a substantial height at that time (e.g. Clift et al., 2008; Jiang and Ding, 2008; Passey et al., 2009). This, however, is not justified by our model results, at least for the Tortonian. Precipitation does increase on our domain average in TORT due to the warmer conditions, but such an increase is quite unevenly distributed and mostly occurs over the ocean (Table 3 ) and the maritime continent (Fig. 4d). Although the elevation of the orography prescribed in TORT (Fig. 3b) may represent the highest scenario in the Tortonian, it still noticeably weakens the monsoon circulation in N-China and the northwestern Indian subcontinent. This limits the penetration of moisture from the ocean to the continent (Fig. 11d) and, hence, results in drier conditions in these areas (Fig. 12f). The competing effects of the lower TP (weakening summer monsoon circulation) and the warmer global conditions (enhancing moisture supply) probably amplified the regional contrasts of the Asian monsoon climate in the Tortonian. How the regional tectonics, global climate and their interactions contributed, respectively, to the spatial heterogeneity of Asian monsoon climate in the Late Miocene deserves more study. 


\section{Conclusions}

In this study, we employ a high-resolution regional climate model to simulate the average state of the Asian monsoon climate under thoroughly prescribed boundary conditions for the Tortonian. Our regional model simulation yields a Tortonian Asian monsoon climate that is comparable to our global forcing model on large-scale patterns, but highlights the regional difference of the monsoon climate, and resolves some apparent contradictions in the monsoon proxies of this period. Our results suggest a stronger East Asian winter monsoon wind in the Tortonian as a result of the strengthened global westerly flow and the lower northern Tibetan Plateau. The summer monsoon circulation was generally weaker in the Tortonian. Associated with this was the decrease of monsoon precipitation in northern China and northern India, but increase of precipitation over southern China and southern India. The Köppen climate classification implies an earlier presence of strong monsoonal climate in southern China and most of India, and a later onset of monsoonal climate in northern China and the foreland basin of the western Himalayas in the Tortonian. While the changes of summer monsoon over South Asia and southern China are mainly controlled by global climate conditions (e.g. warmer sea surface temperature), the summer monsoon over northern China is more susceptible to regional orographic changes (e.g. lower northern Tibetan Plateau). In such a way, the competing effects of global climate versus the effects of regional tectonics could have maintained the regional heterogeneity of the Asian monsoon climate in the Tortonian.

Our study is designed to simulate the most probable scenario of the Asian monsoon climate in the Tortonian. Nevertheless, given the large uncertainties of our knowledge on the Late Miocene boundary conditions, such as the palaeoaltitude of the Tibetan Plateau and other orography, more studies combining sensitivity experiments with both global and regional models are necessary to fully quantify the range of regional variation of the Asian monsoon climate in the Late Miocene.

\section{Supplementary material related to this article is available online at: http://www.clim-past.net/7/847/2011/ cp-7-847-2011-supplement.zip.}

Acknowledgements. We gratefully acknowledge the valuable comments of Alan Haywood, an anonymous reviewer, and the editor that improved our manuscript. We thank the Ella and Georg Ehrnrooth foundation for project funding. This work was also financially supported by the Deutsche Forschungsgemeinschaft DFG within the project FOR 1070 and the federal state Hessen (Germany) within the LOEWE initiative, and is a contribution to the NECLIME framework. We acknowledge the model support of the CLM community especially from Andreas Will,
Burkhardt Rockel and Hans-Jürgen Panitz. Our model experiments were performed at the Center for Scientific Computing (CSC) in Espoo (Finland) with special technical support from Juha Lento and Tommi Bergman. We would also like to thank Bodo Ahrens, Andreas Dobler, Mark Herrmann, Liu Liping, Anu Kaakinen, and Zhou Liping for fruitful discussions.

Edited by: M. Claussen

\section{References}

An, Z. S., Kutzbach, J. E., Prell, W. L., and Porter, S. C.: Evolution of Asian monsoons and phased uplift of the Himalayan Tibetan plateau since Late Miocene times, Nature, 411, 62-66, 2001.

Armstrong-Altrin, J. S., Lee, Y. I., Verma, S. P., and Worden, R. H.: Carbon, oxygen, and strontium isotope geochemistry of carbonate rocks of the upper Miocene Kudankulam Formation, southern India: Implications for paleoenvironment and diagenesis, Chemie Der Erde-Geochemistry, 69, 45-60, 2009.

Ashfaq, M., Shi, Y., Tung, W. W., Trapp, R. J., Gao, X. J., Pal, J. S., and Diffenbaugh, N. S.: Suppression of south Asian summer monsoon precipitation in the 21 st century, Geophys. Res. Lett., 36, L01704, doi:10.1029/2008GL036500, 2009.

Beck, C., Grieser, J., and Rudolf, B.: A new monthly precipitation climatology for the global land areas for the period 1951 to 2000 , Climate status report 2004, German Weather Service, Offenbach, Germany, 2005.

Blisniuk, P. M., Hacker, B. R., Glodny, J., Ratschbacher, L., Bi, S. W., Wu, Z. H., McWilliams, M. O., and Calvert, A.: Normal faulting in central Tibet since at least 13.5 Myr ago, Nature, 412, 628-632, 2001.

Böhm, U., Kücken, M., Ahrens, W., Block, A., Hauffe, D., Keuler, K., Rockel, B., and Will, A.: CLM - the climate version of LM: brief description and long-term applications, COSMO Newsletter, 6, 225-235, 2006.

Boos, W. R. and Kuang, Z. M.: Dominant control of the South Asian monsoon by orographic insulation versus plateau heating, Nature, 436, 218-223, 2010.

Cane, M. A. and Molnar, P.: Closing of the Indonesian seaway as a precursor to east African aridircation around 3-4 million years ago, Nature, 411, 157-162, 2001.

Chakraborty, A., Nanjundiah, R. S., and Srinivasan, J.: Role of Asian and African orography in Indian summer monsoon, Geophys. Res. Lett., 29, 1989, doi:10.1029/2002GL015522, 2002.

Chang, C. P., Zhang, Y. S., and Li, T.: Interannual and interdecadal variations of the East Asian summer monsoon and tropical Pacific SSTs. Part I: Roles of the subtropical ridge, J. Climate, 13, 4310-4325, 2000.

Charreau, J., Chen, Y., Gilder, S., Barrier, L., Dominguez, S., Augier, R., Sen, S., Avouac, J. P., Gallaud, A., Graveleau, F., and Wang, Q. C.: Neogene uplift of the Tian Shan Mountains observed in the magnetic record of the Jingou River section (northwest China), Tectonics, 28, TC2008, doi:10.1029/2007TC002137, 2009.

Christensen, J. H. and Christensen, O. B.: A summary of the PRUDENCE model projections of changes in European climate by the end of this century, Climatic Change, 81, 7-30, 2007. 
Clift, P. D., Hodges, K. V., Heslop, D., Hannigan, R., Van Long, H., and Calves, G.: Correlation of Himalayan exhumation rates and Asian monsoon intensity, Nat. Geosci., 1, 875-880, 2008.

Coleman, M. and Hodges, K.: Evidence for Tibetan Plateau Uplift before 14-Myr Ago from a New Minimum Age for East-West Extension, Nature, 374, 49-52, 1995.

Collins, L. S., Coates, A. G., Berggren, W. A., Aubry, M. P., and Zhang, J. J.: The late Miocene Panama isthmian strait, Geology, 24, 687-690, 1996.

Derry, L. A. and FranceLanord, C.: Neogene Himalayan weathering history and river Sr-87/Sr-86: Impact on the marine Sr record, Earth Planet. Sci. Lett., 142, 59-74, 1996.

Dettman, D. L., Kohn, M. J., Quade, J., Ryerson, F. J., Ojha, T. P., and Hamidullah, S.: Seasonal stable isotope evidence for a strong Asian monsoon throughout the past $10.7 \mathrm{~m} . \mathrm{y}$, Geology, 29, 3134, 2001.

Dettman, D. L., Fang, X. M., Garzione, C. N., and Li, J. J.: Upliftdriven climate change at $12 \mathrm{Ma}$ : a long $\delta^{18} \mathrm{O}$ record from the NE margin of the Tibetan plateau, Earth Planet. Sci. Lett., 214, 267-277, 2003.

Ding, Y. H.: Summer Monsoon Rainfalls in China, Journal of the Meteorological Society of Japan, 70, 373-396, 1992.

Ding, Z. L., Xiong, S. F., Sun, J. M., Yang, S. L., Gu, Z. Y., and Liu, T. S.: Pedostratigraphy and paleomagnetism of a similar to 7.0 Ma eolian loess-red clay sequence at Lingtai, Loess Plateau, north-central China and the implications for paleomonsoon evolution, Palaeogeogr. Palaeocl., 152, 49-66, 1999.

Dobler, A. and Ahrens, B.: Analysis of the Indian summer monsoon system in the regional climate model COSMO-CLM, J. Geophys. Res.-Atmos., 115, D16101, doi:10.1029/2009JD013497, 2010.

Doms, G. and Schattler, U.: A Description of the nonhydrostatic regional model LM (Part I): dynamics and numerics, available at: http://www.cosmo-model.org/, 2002.

Doms, G., Forstner, J., Heis, E., Herzog, H. J., Raschendorfer, M., Reinhardt, T., Ritter, B., Schrodin, R., Schulz, J. P., and Vogel, G.: A description of nonhydrostatic regional model LM (Part II): physical parameterization, available at: http://www. cosmo-model.org/, 2007.

Dong, M. X., Li, F. L., Gao, D. Z., Geng, M. S., and Li, L. Y.: A study of the Late Miocene dry event based on sporo-pollen variations in Sunid Zuoqi, Inner Mongolia, Acta Geoscientica Sinica, 27, 207-212, 2006.

Dutton, J. F. and Barron, E. J.: Miocene to present vegetation changes: A possible piece of the Cenozoic cooling puzzle, Geology, 25, 39-41, 1997.

Eronen, J. T., Ataabadia, M. M., Micheels, A., Karme, A., Bernor, R. L., and Fortelius, M.: Distribution history and climatic controls of the Late Miocene Pikermian chronofauna, P. Nal. A. Sci. USA, 106, 11867-11871, 2009.

Eronen, J. T., Puolamäki, K., Liu, L., Lintulaakso, K., Damuth, J., Janis, C., and Fortelius, M.: Precipitation and large herbivorous mammals , part I: Estimates from present-day communities, Evol. Ecol. Res., 12, 217-233, 2010a.

Eronen, J. T., Puolamäki, K., Liu, L., Lintulaakso, K., Damuth, J., Janis, C., and Fortelius, M.: Precipitation and large herbivorous mammals , part II: Application to fossil data, Evol. Ecol. Res., $12,235-248,2010 b$.
Fluteau, F., Ramstein, G., and Besse, J.: Simulating the evolution of the Asian and African monsoons during the past 30 Myr using an atmospheric general circulation model, J. Geophys. Res.-Atmos., 104, 11995-12018, 1999.

Fortelius, M., Eronen, J., Jernvall, J., Liu, L. P., Pushkina, D., Rinne, J., Tesakov, A., Vislobokova, I., Zhang, Z. Q., and Zhou, L. P.: Fossil mammals resolve regional patterns of Eurasian climate change over 20 million years, Evol. Ecol. Res., 4, 10051016, 2002.

Gadgil, S.: The Indian monsoon and its variability, Annu. Rev. Earth Pl. Sc., 31, 429-467, 2003.

Gao, X. J., Xu, Y., Zhao, Z. C., Pal, J. S., and Giorgi, F.: On the role of resolution and topography in the simulation of East Asia precipitation, Theor. Appl. Climatol., 86, 173-185, 2006.

Gao, X. J., Shi, Y., Song, R., Giorgi, F., Wang, Y., and Zhang, D.: Reduction of future monsoon precipitation over China: comparison between a high resolution RCM simulation and the driving GCM, Meteorol. Atmos. Phys., 100, 73-86, 2008.

Goswami, B. N. and Mohan, R. S. A.: Intraseasonal oscillations and interannual variability of the Indian summer monsoon, J. Climate, 14, 1180-1198, 2001.

Goswami, B. N., Krishnamurthy, V., and Annamalai, H.: A broadscale circulation index for the interannual variability of the Indian summer monsoon, Q. J. Roy. Meteorol. Soc., 125, 611-633, 1999.

Guo, Z. T., Ruddiman, W. F., Hao, Q. Z., Wu, H. B., Qiao, Y. S., Zhu, R. X., Peng, S. Z., Wei, J. J., Yuan, B. Y., and Liu, T. S.: Onset of Asian desertification by $22 \mathrm{Myr}$ ago inferred from loess deposits in China, Nature, 416, 159-163, 2002.

Guo, Z. T., Sun, B., Zhang, Z. S., Peng, S. Z., Xiao, G. Q., Ge, J. Y., Hao, Q. Z., Qiao, Y. S., Liang, M. Y., Liu, J. F., Yin, Q. Z., and Wei, J. J.: A major reorganization of Asian climate by the early Miocene, Clim. Past, 4, 153-174, doi:10.5194/cp-4-153-2008, 2008.

Harris, N.: The elevation history of the Tibetan Plateau and its implications for the Asian monsoon, Palaeogeogr. Palaeocl., 241, 4-15, 2006.

Harzhauser, M. and Piller, W. E.: Benchmark data of a changing sea - Palaeogeography, palaeobiogeography and events in the Central Paratethys during the Miocene, Palaeogeogr. Palaeocl., 253, 8-31, 2007.

Herold, N., Seton, M., Muller, R. D., You, Y., and Huber, M.: Middle Miocene tectonic boundary conditions for use in climate models, Geochem. Geophys. Geosyst., 9, Q10009, doi:10.1029/2008GC002046, 2008.

Hollweg, H. D., Bohm, U., Fast, I., Hennemuth, B., Keuler, K., Keup-Thiel, E., Lautenschlager, M., and Legutke, S.: Ensemble simulations over Europe with the regional climate model CLM forced with IPCC AR4 global scenarios, Tech. Rep. 3, M\&D, Max Planck Institute for Meteorology, 2008.

Hoorn, C., Ohja, T., and Quade, J.: Palynological evidence for vegetation development and climatic change in the Sub-Himalayan Zone (Neogene, Central Nepal), Palaeogeogr. Palaeocl., 163, 133-161, 2000.

Huang, Y. S., Clemens, S. C., Liu, W. G., Wang, Y., and Prell, W. L.: Large-scale hydrological change drove the late Miocene $\mathrm{C}_{4}$ plant expansion in the Himalayan foreland and Arabian Peninsula, Geology, 35, 531-534, 2007. 
Jacques, F. M. B., Guo, S. X., Su, T., Xing, Y. W., Huang, Y. J., Liu, Y. S., Ferguson, D. K., and Zhou, Z. K.: Quantitative reconstruction of the Late Miocene monsoon climates of southwest China: A case study of the Lincang flora from Yunnan Province, Palaeogeogr. Palaeocl., 304, 318-327, 2011.

Jaeger, E. B., Anders, I., Luthi, D., Rockel, B., Schar, C., and Seneviratne, S. I.: Analysis of ERA40-driven CLM simulations for Europe, Meteorologische Zeitschrift, 17, 349-367, 2008.

Jia, G. D., Peng, P. A., Zhao, Q. H., and Jian, Z. M.: Changes in terrestrial ecosystem since $30 \mathrm{Ma}$ in East Asia: Stable isotope evidence from black carbon in the South China Sea, Geology, 31, 1093-1096, 2003.

Jiang, H. C. and Ding, Z. L.: Spatial and temporal characteristics of Neogene palynoflora in China and its implication for the spread of steppe vegetation, J. Arid Environ., 73, 765-772, 2009.

Jiang, H. C. and Ding, Z. L.: A 20 Ma pollen record of East-Asian summer monsoon evolution from Guyuan, Ningxia, China, Palaeogeogr. Palaeocl., 265, 30-38, 2008.

Ju, L. X., Wang, H. K., and Jiang, D. B.: Simulation of the Last Glacial Maximum climate over East Asia with a regional climate model nested in a general circulation model, Palaeogeogr. Palaeocl., 248, 376-390, 2007.

Kaakinen, A., Sonninen, E., and Lunkka, J. P.: Stable isotope record in paleosol carbonates from the Chinese Loess Plateau: Implications for late Neogene paleoclimate and paleovegetation, Palaeogeogr. Palaeocl., 237, 359-369, 2006.

Kottek, M., Grieser, J., Beck, C., Rudolf, B., and Rubel, F.: World map of the Köppen-Geiger climate classification updated, Meteorologische Zeitschrift, 15, 259-263, 2006.

Kroon, D., Steens, T., and Troelstra, S. R.: Onset of monsoonal related upwelling in the western Arabian Sea as revealed by planktonic foraminifers, Proceedings of the Ocean Drilling Program, 117, 257-263, 1991.

Kutzbach, J. E., Prell, W. L., and Ruddiman, W. F.: Sensitivity of Eurasian Climate to Surface Uplift of the Tibetan Plateau, J. Geol., 101, 177-190, 1993.

Lacombe, O., Mouthereau, F., Kargar, S., and Meyer, B.: Late Cenozoic and modern stress fields in the western Fars (Iran): Implications for the tectonic and kinematic evolution of central Zagros, Tectonics, 25, TC1003, doi:10.1029/2005TC001831, 2006.

Li, J. G. and Zhang, Y. Y.: Neogene palynofloras from east offshore, Hainan Island, Acta Palaeontologica Sinica, 15, 323-330, 1998.

Liu, G. W.: Late Cenozoic palynological sequence of Eastern Qinghai-Xizang Plateau and its bearing on palaeogeography, Acta Micropalaeontologica Sinica, 13, 363-372, 1996.

Liu, G. W.: A Miocene palynoflora from Huanan County of Heilongjiang Province, Northeastern China, Acta Micropalaeontologica Sinica, 15, 48-54, 1998.

Liu, J., Wang, B., and Yang, J.: Forced and internal modes of variability of the East Asian summer monsoon, Clim. Past, 4, 225233, doi:10.5194/cp-4-225-2008, 2008.

Liu, L. P., Eronen, J. T., and Fortelius, M.: Significant midlatitude aridity in the middle Miocene of East Asia, Palaeogeogr. Palaeocl., 279, 201-206, 2009.

Liu, X. D. and Yin, Z. Y.: Sensitivity of East Asian monsoon climate to the uplift of the Tibetan Plateau, Palaeogeogr. Palaeocl., 183, 223-245, 2002.
Liu, Y. S., Utescher, T., Zhou, Z., and Sun, B.: The evolution of Miocene climates in North China: Preliminary results of quantitative reconstructions from plant fossil records, Palaeogeogr. Palaeocl., 304, 308-317, 2011.

Liu-Zeng, J., Tapponnier, P., Gaudemer, Y., and Ding, L.: Quantifying landscape differences across the Tibetan plateau: Implications for topographic relief evolution, J. Geophys. Res.-Earth Surface, 113, F04018, doi:10.1029/2007jf000897, 2008.

Lunt, D. J., Flecker, R., Valdes, P. J., Salzmann, U., Gladstone, R., and Haywood, A. M.: A methodology for targeting palaeo proxy data acquisition: A case study for the terrestrial late Miocene, Earth Planet. Sci. Lett., 271, 53-62, 2008.

Ma, Y. Z., Li, J. J., and Fang, X. M.: Pollen assemblage in 30.65.0 Ma redbeds of Linxia region and climate evolution, Chinese Science Bulletin, 43, 301-304, 1998.

Ma, Y. Z., Fang, X. M., Li, J. J., Wu, F. L., and Zhang, J.: The vegetation and climate change during Neocene and Early Quaternary in Jiuxi Basin, China, Science in China Series D-Earth Sciences, 48, 676-688, 2005.

Micheels, A., Bruch, A. A., Uhl, D., Utescher, T., and Mosbrugger, V.: A Late Miocene climate model simulation with ECHAM4/ML and its quantitative validation with terrestrial proxy data, Palaeogeogr. Palaeocl., 253, 251-270, 2007.

Micheels, A., Bruch, A., and Mosbrugger, V.: Miocene climate modelling sensitivity experiments for different $\mathrm{CO}_{2}$ concentrations, Palaeontologia Electronica, 12(5A), p. 20, 2009a.

Micheels, A., Eronen, J., and Mosbrugger, V.: The Late Miocene climate response to a modern Sahara desert, Global Planet. Change, 67, 193-204, 2009b.

Micheels, A., Bruch, A. A., Eronen, J., Fortelius, M., Harzhauser, M., Utescher, T., and Mosbrugger, V.: Analysis of heat transport mechanisms from a Late Miocene model experiment with a fullycoupled atmosphere-ocean general circulation model, Palaeogeogr. Palaeocl., 304, 337-350, 2011.

Mikolajewicz, U. and Crowley, T. J.: Response of a coupled ocean/energy balance model to restricted flow through the central American isthmus, Paleoceanography, 12, 429-441, 1997.

Mitchell, T. D. and Jones, P. D.: An improved method of constructing a database of monthly climate observations and associated high-resolution grids, Int. J. Climatol., 25, 693-712, 2005.

Molnar, P., Boos, W. R., and Battisti, D. S.: Orographic controls on climate and paleoclimate of Asia: Thermal and mechanical roles for the Tibetan Plateau, Annu. Rev. Earth Pl. Sc., 38, 77-102, 2010.

Park, S. and Hong, S. Y.: The role of surface boundary forcing over south Asia in the Indian summer monsoon circulation: A regional climate model sensitivity study, Geophys. Res. Lett., 31, L12112, doi:10.1029/2004GL019729, 2004.

Passey, B. H., Ayliffe, L. K., Kaakinen, A., Zhang, Z. Q., Eronen, J. T., Zhu, Y. M., Zhou, L. P., Cerling, T. E., and Fortelius, M.: Strengthened East Asian summer monsoons during a period of high-latitude warmth? Isotopic evidence from Mio-Pliocene fossil mammals and soil carbonates from northern China, Earth Planet. Sci. Lett., 277, 443-452, 2009.

Pearson, P. N. and Palmer, M. R.: Atmospheric carbon dioxide concentrations over the past 60 million years, Nature, 406, 695-699, 2000 . 
Popov, S. V., Rögl, F., Rozanov, A. Y., Steininger, F., Shcherba, I., and Kovac, M.: Lithological-Paleogeographic maps of Paratethys: 10 Maps Late Eocene to Pliocene, Courier Forschungsinstitut Senckenberg, 250, 1-46, 2004.

Qiang, X. K., Li, Z. X., Powell, C. M., and Zheng, H. B.: Magnetostratigraphic record of the Late Miocene onset of the East Asian monsoon, and Pliocene uplift of northern Tibet, Earth Planet. Sci. Lett., 187, 83-93, 2001.

Quade, J., Cerling, T. E., and Bowman, J. R.: Development of Asian monsoon revealed by marked ecological shift during the Latest Miocene in Northern Pakistan, Nature, 342, 163-166, 1989.

Ramstein, G., Fluteau, F., Besse, J., and Joussaume, S.: Effect of orogeny, plate motion and land sea distribution on Eurasian climate change over the past 30 million years, Nature, 386, 788795, 1997.

Raschendorfer, M.: The new turbulence parameterization of LM, COSMO newsletter, 1, 90-98, 2001.

Rea, D. K., Snoeckx, H., and Joseph, L. H.: Late Cenozoic eolian deposition in the North Pacific: Asian drying, Tibetan uplift, and cooling of the northern hemisphere, Paleoceanography, 13, 215224, 1998.

Rockel, B. and Geyer, B.: The performance of the regional climate model CLM in different climate regions, based on the example of precipitation, Meteorologische Zeitschrift, 17, 487-498, 2008.

Rowley, D. B. and Currie, B. S.: Palaeo-altimetry of the late Eocene to Miocene Lunpola basin, central Tibet, Nature, 439, 677-681, 2006.

Rowley, D. B., Pierrehumbert, R. T., and Currie, B. S.: A new approach to stable isotope-based paleoaltimetry: implications for paleoaltimetry and paleohypsometry of the High Himalaya since the Late Miocene, Earth Planet. Sci. Lett., 188, 253-268, 2001.

Ruddiman, W. F. and Kutzbach, J. E.: Forcing of late Cenozoic Northern Hemisphere climate by plateau uplift in Southern Asia and the American West, J. Geophys. Res.-Atmos., 94, 1840918427, 1989.

Sakai, K. and Kawamura, R.: Remote response of the East Asian winter monsoon to tropical forcing related to El NiñoSouthern Oscillation, J. Geophys. Res.-Atmos., 114, D06105, doi:10.1029/2008JD010824, 2009.

Sanyal, P., Sarkar, A., Bhattacharya, S. K., Kumar, R., Ghosh, S. K., and Agrawal, S.: Intensification of monsoon, microclimate and asynchronous $\mathrm{C}_{4}$ appearance: Isotopic evidence from the Indian Siwalik sediments, Palaeogeogr. Palaeocl., 296, 165-173, 2010.

Schrodin, R. and Heise, E.: A new multi-layer soil model, COSMO Newsletter, 2, 149-151, 2002.

Shu, J. W., Wang, W. M., Leopold, E. B., Wang, J. S., and Yin, D. S.: Pollen stratigraphy of coal-bearing deposits in the Neogene Jidong Basin, Heilongjiang Province, NE China: New insights on palaeoenvironment and age, Rev. Palaeobot. Palyno., 148, 163-183, 2008

Singh, G. P. and Oh, J. H.: Impact of Indian Ocean sea-surface temperature anomaly on Indian summer monsoon precipitation using a regional climate model, Int. J. Climatol., 27, 1455-1465, 2007.

Skamarock, W. C. and Klemp, J. B.: The stability of time-split numerical-methods for the hydrostatic and the nonhydrostatic elastic equations, Mon. Weather Rev., 120, 2109-2127, 1992.
Smiatek, G., Rockel, B., and Schattler, U.: Time invariant data preprocessor for the climate version of the COSMO model (COSMO-CLM), Meteorologische Zeitschrift, 17, 395-405, 2008.

Spicer, R. A., Harris, N. B. W., Widdowson, M., Herman, A. B., Guo, S. X., Valdes, P. J., Wolfe, J. A., and Kelley, S. P.: Constant elevation of southern Tibet over the past 15 million years, Nature, 421, 622-624, 2003.

Steinke, S., Groeneveld, J., Johnstone, H., and Rendle-Buhring, R.: East Asian summer monsoon weakening after 7.5 Ma: Evidence from combined planktonic foraminifera $\mathrm{Ma} / \mathrm{Ca}$ and $\delta^{18} \mathrm{O}(\mathrm{ODP}$ site 1146; northern South China Sea), Palaeogeogr. Palaeocl., 289, 33-43, 2010.

Steppuhn, A., Micheels, A., Geiger, G., and Mosbrugger, V.: Reconstructing the Late Miocene climate and oceanic heat flux using the AGCM ECHAM4 coupled to a mixed-layer ocean model with adjusted flux correction, Palaeogeogr. Palaeocl., 238, 399423, 2006.

Steppuhn, A., Micheels, A., Bruch, A. A., Uhl, D., Utescher, T., and Mosbrugger, V.: The sensitivity of ECHAM4/ML to a double $\mathrm{CO}_{2}$ scenario for the Late Miocene and the comparison to terrestrial proxy data, Global Planet. Change, 57, 189-212, 2007.

Sun, D. H.: Monsoon and westerly circulation changes recorded in the late Cenozoic aeolian sequences of Northern China, Global Planet. Change, 41, 63-80, 2004.

Sun, D. H., Shaw, J., An, Z. S., Cheng, M. Y., and Yue, L. P.: Magnetostratigraphy and paleoclimatic interpretation of a continuous 7.2Ma Late Cenozoic eolian sediments from the Chinese Loess Plateau, Geophys. Res. Lett., 25, 85-88, 1998.

Sun, J. M. and Zhang, Z. Q.: Palynological evidence for the MidMiocene Climatic Optimum recorded in Cenozoic sediments of the Tian Shan Range, northwestern China, Global Planet Change, 64, 53-68, 2008.

Sun, J. M., Zhang, Z. Q., and Zhang, L. Y.: New evidence on the age of the Taklimakan Desert, Geology, 37, 159-162, 2009.

Sun, X. J. and Wang, P. X.: How old is the Asian monsoon system? Palaeobotanical records from China, Palaeogeogr. Palaeocl., 222, 181-222, 2005.

Tang, L. Y. and Shen, C. M.: Late Cenozoic vegetational history and climatic characteristics of Qinghai-Xizang Plateau, Acta Micropalaeontologica Sinica, 13, 321-337, 1996.

Tapponnier, P., Xu, Z. Q., Roger, F., Meyer, B., Arnaud, N., Wittlinger, G., and Yang, J. S.: Oblique stepwise rise and growth of the Tibet plateau, Science, 294, 1671-1677, 2001.

Tiedtke, M.: A comprehensive mass flux scheme for cumulus parameterization in large-scale models, Mon. Weather Rev., 117, 1779-1800, 1989.

Wan, S. M., Li, A. C., Clift, P. D., and Stuut, J. B. W.: Development of the East Asian monsoon: Mineralogical and sedimentologic records in the northern South China Sea since $20 \mathrm{Ma}$, Palaeogeogr. Palaeocl., 254, 561-582, 2007.

Wang, B., Wu, Z. W., Li, J. P., Liu, J., Chang, C. P., Ding, Y. H., and $\mathrm{Wu}, \mathrm{G}$. X.: How to measure the strength of the East Asian summer monsoon, J. Climate, 21, 4449-4463, 2008a.

Wang, H. J. and Jiang, D. B.: A new East Asian winter monsoon intensity index and atmospheric circulation comparison between strong and weak composite, Quaternary Sci., 24, 19-27, 2004. 
Wang, J., Wang, Y. J., Liu, Z. C., Li, J. Q., and Xi, P.: Cenozoic environmental evolution of the Qaidam Basin and its implications for the uplift of the Tibetan Plateau and the drying of central Asia, Palaeogeogr. Palaeocl., 152, 37-47, 1999.

Wang, P. X., Clemens, S., Beaufort, L., Braconnot, P., Ganssen, G., Jian, Z. M., Kershaw, P., and Sarnthein, M.: Evolution and variability of the Asian monsoon system: state of the art and outstanding issues, Quaternary Sci. Rev., 24, 595-629, 2005.

Wang, W. M., Saito, T., and Nakagawa, T.: Palynostratigraphy and climatic implications of Neogene deposits in the Himi area of Toyama Prefecture, Central Japan, Rev. Palaeobot. Palyno., 117, 281-295, 2001.

Wang, Y., Wang, X. M., Xu, Y. F., Zhang, C. F., Li, Q., Tseng, Z. J., Takeuchi, G., and Deng, T.: Stable isotopes in fossil mammals, fish and shells from Kunlun Pass Basin, Tibetan Plateau: Paleo-climatic and paleo-elevation implications, Earth Planet. Sci. Lett., 270, 73-85, 2008b.

Webster, P. J., Magana, V. O., Palmer, T. N., Shukla, J., Tomas, R. A., Yanai, M., and Yasunari, T.: Monsoons: Processes, predictability, and the prospects for prediction, J. Geophys. Res.Oceans, 103, 14451-14510, 1998.

Wolfe, J. A.: Distribution of major vegetation types during the Tertiary, in: The carbon cycle and atmospheric $\mathrm{CO}_{2}$ : Natural Variations Archean to Present, edited by Sundquist, E. T. and Broecker, W. S., 357-375, AGU, Washington, D.C., 1985.

Xia, K., Su, T., Liu, Y. S., Xing, Y. W., Jacques, F. M. B., and Zhou, Z. K.: Quantitative climate reconstructions of the late Miocene Xiaolongtan megaflora from Yunnan, southwest China, Palaeogeogr. Palaeocl., 276, 80-86, 2009.

Yue, X., Wang, H. J., Wang, Z. F., and Fan, K.: Simulation of dust aerosol radiative feedback using the Global Transport Model of Dust: 1. Dust cycle and validation, J. Geophys. Res.-Atmos., 114, D10202, doi:10.1029/2008JD010995, 2009.

Zachos, J., Pagani, M., Sloan, L., Thomas, E., and Billups, K.: Trends, rhythms, and aberrations in global climate 65 Ma to present, Science, 292, 686-693, 2001.
Zhang, Z. S., Wang, H. J., Guo, Z. T., and Jiang, D. B.: Impacts of tectonic changes on the reorganization of the Cenozoic paleoclimatic patterns in China, Earth Planet. Sci. Lett., 257, 622-634, 2007a.

Zhang, Z. S., Wang, H. J., Guo, Z. T., and Jiang, D. B.: What triggers the transition of palaeoenvironmental patterns in China, the Tibetan Plateau uplift or the Paratethys Sea retreat?, Palaeogeogr. Palaeocl., 245, 317-331, 2007b.

Zheng, D. W., Zhang, P. Z., Wan, J. L., Yuan, D. Y., Li, C. Y., Yin, G. M., Zhang, G. L., Wang, Z. C., Min, W., and Chen, J.: Rapid exhumation at similar to $8 \mathrm{Ma}$ on the Liupan Shan thrust fault from apatite fission-track thermochronology: Implications for growth of the northeastern Tibetan Plateau margin, Earth Planet. Sci. Lett., 248, 198-208, 2006.

Zheng, H. B., Powell, C. M., An, Z. S., Zhou, J., and Dong, G. R.: Pliocene uplift of the northern Tibetan Plateau, Geology, 28, 715-718, 2000.

Zheng, Y. H. and Wang, W. X.: Sequence of Miocene Fotan Group in SE Fujian and its palyno-assemblages, Acta Palaeontologica Sinica, 33, 200-218, 1994.

Zheng, Y. Q., Yu, G., Wang, S. M., Xue, B., Zhuo, D. Q., Zeng, X. M., and Liu, H. Q.: Simulation of paleoclimate over East Asia at $6 \mathrm{ka} \mathrm{BP}$ and $21 \mathrm{ka} \mathrm{BP}$ by a regional climate model, Clim. Dynam., 23, 513-529, 2004.

Zhu, J. H. and Wang, S. W.: $80 \mathrm{yr}$ oscillation of summer rainfall over North China and East Asian Summer Monsoon, Geophys. Res. Lett., 29, 1672, doi:10.1029/2001GL013997, 2002.

Zhu, Y. M., Zhou, L. P., Mo, D. W., Kaakinen, A., Zhang, Z. Q., and Fortelius, M.: A new magnetostratigraphic framework for late Neogene Hipparion Red Clay in the eastern Loess Plateau of China, Palaeogeogr. Palaeocl., 268, 47-57, 2008. 